\title{
Morphology and affinities of Eridostracina: Palaeozoic ostracods with moult retention
}

\author{
Ewa Olempska
}

Published online: 16 March 2011

(C) The Author(s) 2011. This article is published with open access at Springerlink.com

\begin{abstract}
Ostracods are by far the most abundant living group of arthropods in the fossil record. Traditionally, eridostracines were classified as members of the Class Ostracoda. They have also been considered to represent extinct marine spinicaudatan (conchostracan) branchiopods. The ostracod affinity of the Eridostracina is evident in a number of features such as the muscle scars pattern, the hinge structure, the presence of an adductorial sulcus reflected as a ridge on the internal surface and the separation at the dorsal margin of successive valves. The eridostracines might be a polyphyletic group, containing aberrant representatives of ostracods, with ancestors probably among the conchoprimitid, leperditellid and beyrichioidean ostracod species. The Eridostracina represent an extinct group of small marine crustaceans with a multilayer structure of the calcified carapace, formed through the retention of unshed moults during the growth process. Details of the morphology of the eridostracine Cryptophyllus socialis from the Upper Devonian of Russia are reconstructed using the process of exfoliation of successive exuviae. 'Double-sided' hingement structures were found in the accumulated exuviae. It is
\end{abstract}

Guest Editors: D. A. Do Carmo, R. L. Pinto \& K. Martens / Ostracoda - Biostratigraphy and Applied Ecology

E. Olempska ( $\square)$

Institute of Paleobiology, Polish Academy of Sciences,

Twarda 51/55, 00-818 Warszawa, Poland

e-mail: olempska@twarda.pan.pl suggested that the main function of these structures was the strengthening of the connection between the accumulated valves. The hingement of Cryptophyllus represents a vestigial structure, which has lost its original function as a pivot, a role documented in the ancestors of that genus. Tubular structures were found attached to the internal side of the calcite layer. It is suggested that they also represent vestigial pore canals, having lost their original function as sensory receptors. External surfaces of the attached exuviae bear imprints of the tubular structures of the overlying exuviae. These imprints originated probably due to the strong pressure of the new cuticle against the old one, during the very short moulting time. During this process, the freshly formed cuticle was at its final size, but still soft and non-calcified. A number of three-dimensionally preserved cell-like structures were recovered inside the interlayer chambers.

Keywords Ostracoda $\cdot$ Eridostracina $\cdot$ Moult retention - Vestigial structures - Cell-like structures · Palaeozoic

\section{Introduction}

The Eridostracina are a poorly known group of marine crustaceans, traditionally assigned to the Class Ostracoda. However, this affiliation has been questioned based on similarities, regarding moult retention, to the former 'Conchostraca' (Laevicaudata, Spinicaudata 
and Cyclestherida). The calcareous carapace of the eridostracines bears a series of 'growth lines' on the external surface of the valves, which reflect successive sheets of cuticle retained within each other, instead of being fully shed during ecdysis. Within a single carapace up to 15 exuviae (including the first larval stage) underlying one another may be retained (Figs. 1, 2).

Multilayered eridostracines first appear in the fossil record in the Middle Ordovician (Darrwillian). The youngest known occurrence of Cryptophyllus is in the Middle Carboniferous (Serpukhovian) of Patagonia, Argentina (Díaz Saravia \& Jones, 1999). Eridostracine fossils have a world-wide distribution in shallow marine environments from tropical to subtropical areas (e.g. Egorov, 1954; Adamczak, 1961; Jones, 1962, 1968, 1989; Le Fevre, 1963; Becker \& Sanchez de Posada, 1977; Copeland, 1977; Weyant, 1980; Schallreuter, 1981; Bless \& Massa, 1982; Wei, 1988).

Arthropods grow by shedding their exoskeleton and replacing it with a new one that is slightly larger. The retention of exuviae is characteristic of spinicaudatan (conchostracan) branchiopods (see Thiéry, 1996). Branchiopods occur in non-marine facies from the Devonian to the present day. Unquestionable spinicaudatans, with the soft parts preserved, have been found in the Upper Carboniferous deposits of Ireland and France (e.g. Orr \& Briggs, 1999; Vannier et al., 2003; Orr et al., 2008). The 'conchostracan' Estheria diensti Gross, 1934, classified on the basis of the carapace outline and growth band ornamentation similar to that in Recent spinicaudatans, was described from the Lower Devonian Willwerath Lagerstätte of Germany interpreted as a brackish complex (Gross, 1934).

The classification of Recent crustaceans is based largely on external limb and other soft-part morphology. There are essential differences in the body anatomy between the ostracods and spinicaudatans. Ostracods have reduced trunk segmentation and up to eight pairs of limbs in the adult stage, including the male copulatory appendages. In addition, their posterior body region generally exhibits a pair of caudal rami (see Horne et al., 2002). Spinicaudatans have small uniramous antennules, biramous flagelliform antennae, mandibules without palps, small maxillules, vestigial or no maxillae, up to 32 trunk segments, all bearing appendages similar to the phyllopods, and a telson. The body of a spinicaudatan is attached anterodorsally to the carapace only by a ligament and a pair of adductor muscles (Tasch, 1969; Schram, 1986; Martin, 1992; Thiéry, 1996).

Hitherto, complete morphologic studies on the eridostracines have been lacking. The current work investigates on the carapace of the ca. $370 \mathrm{Ma}$ old Cryptophyllus socialis (Eichwald, 1860) from the lower Famennian (Upper Devonian, Palmatolepis crepida Biozone, Zadonsk Horizon) of the Central Devonian Field (Kamenka section, Voronezh region), Russia (Sokiran, 2002, 2003). Specimens of $C$. socialis have been selected for study because of the perfect preservation of features such as muscle scars and hinge, tubular and cell-like structures. Several closely related species have been described under the name Cryptophyllus socialis by Russian researchers. It was described initially (Eichwald, 1860) from the Famennian (Lebedyan Horizon) of the Russian Platform (Egorov, 1954). Species of Cryptophyllus, Eridoconcha and Schaefericoncha from the Devonian of the Holy Cross Mountains in Poland and north-western Poland have also been studied.

\section{Assignment of eridostracines}

Small marine species with multilamellar carapaces were first described by Eichwald (1860) from the Upper Devonian of the Russian Platform; they were referred to as Astarte socialis (=Cryptophyllus socialis) assigned to the Acephala (Lamellibranchiata and Bivalvia). Subsequently, Clarke (1882) described a small marine species from the Middle Devonian (Hamilton) of Ontario, USA, under the name Estheria pulex and interpreted it as a phyllopod. Raymond (1946) redescribed Clarke's species, introduced the new genus Rhabdostichus (type species: Estheria pulex Clarke, 1882) and placed it within an uncertain taxon of the Crustacea, suggesting that 'it may be one of the marine ancestors of the fresh-water Conchostraca'. Rusconi (1954) erected the family Rhabdostichidae and placed it within the conchostracans. Similarly, Novozhilov (in Orlov, 1960) and Tasch (1969) considered Rhabdostichus as a member of the Conchostraca. Rome \& Goreux (1960, p. 191) and Jones (1962, p. 5) suggested that Cryptophyllus may be a junior subjective synonym of Rhabdostichus; 

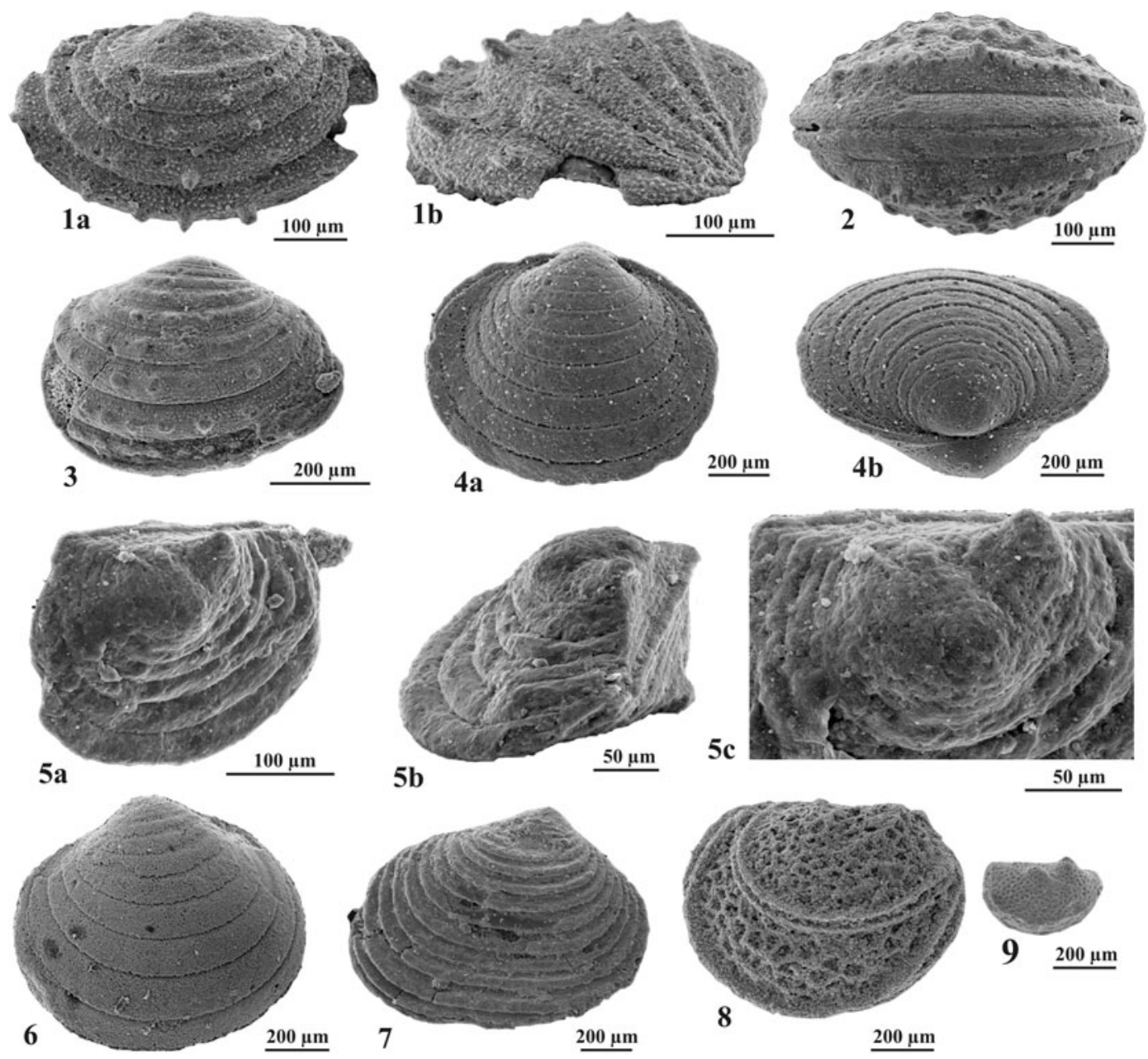

Fig. 1 Scanning electron micrographs showing the external morphology of selected eridostracine species: 1-2 Eridoconcha papillosa Zagora, 1966, Middle Devonian (Skały Formation), Skały, Holy Cross Mountains, Poland. 1a, RV, lat.; 1b, pos. (ZPAL O.59/305); 2 C, ven. (ZPAL O.59/306). 3 Eridoconcha granulifera Adamczak, 1961, Middle Devonian (Skały Formation), Skały, Holy Cross Mountains, Poland; C, left lat. (ZPAL O.59/307). 4 Cryptophyllus plicatus (Adamczak, 1961), Early Devonian (Emsian, Grzegorzowice Formation), Wydryszów, Holy Cross Mountains, Poland; 4a, C, left lat., 4b, oblique dor. (ZPAL O.59/308). 5 Schaefericoncha dorsospina (Blumenstengel, 1997), Late Devonian (Frasnian), Koczała borehole, NW Poland; 5a, C, right lat., 5b, oblique ant., 5c,

according to these authors, however, only a restudy of the original material of Rhabdostichus would indicate if the latter genus is a valid taxon (see 'Discussion' in Schallreuter, 1981). Ulrich \& Bassler (1923, p. 297) described and figured Eridoconcha oboloides, with a multilayered carapace from the Middle Ordovician of close-up of first juvenile valve (ZPAL O.59/309). 6 Cryptophyllus sp., Middle Devonian (Givetian), Jurkowice-Budy, Holy Cross Mountains, Poland, RV, lat. (ZPAL O.59/278). 7 Eridoconcha sp., Early Devonian (U. Pragian), Santo Domingo section, Spain (ZPAL O.59/283). 8-9 Kozlowskiella corbis (Dahmer, 1927), Early Devonian (Emsian, Grzegorzowice Formation), Wydryszów, Holy Cross Mountains, Poland. 8, $\mathrm{RV}$, lat., two valves intact (ZPAL O.59/158). 9, C, right lat., first juvenile valve (ZPAL O.59/160). Abbreviations: $C$ carapace, $R V$ right valve, $L V$ left valve, $A M S$ adductor muscle scar, $F r$. frontal scar, ext. external view, int. internal view, lat. lateral view, ant. anterior view, pos. posterior view, ven. ventral view, dor. dorsal view, obl. oblique view

Minnesota and assigned it to the ostracod family Aparchitidae.

Subsequently, bivalved multilayered marine arthropod species have been assigned to the Ostracoda, based on the presence of the adductorial sulcus and the similarity of the external surfaces of the 
Fig. 2 Schematic drawings of selected eridostracine species to show their external morphology and their first juvenile valves. 1 Americoncha dubia Warshauer \& Berdan, 1982, late Middle Ordovician to early Late Ordovician, Central Kentucky (after Warshauer \& Berdan, 1982). 2 Cryptophyllus gutta Schallreuter, 1968, Late Ordovician,

Öjlemyrflint erratic boulder, Isle of Gotland (after Schallreuter, 1977). 3 Cryptophyllus plicatus (Adamczak, 1961), Early Devonian (Emsian, Grzegorzowice Formation), Wydryszów, Holy Cross Mountains, Poland. 4 Eridoconcha papillosa Zagora, 1966, Middle Devonian (Skały Formation), Skały, Holy Cross Mountains, Poland. 5 Schaefericoncha dorsospina (Blumenstengel, 1997), Late Devonian (Frasnian), Koczała borehole, NW Poland
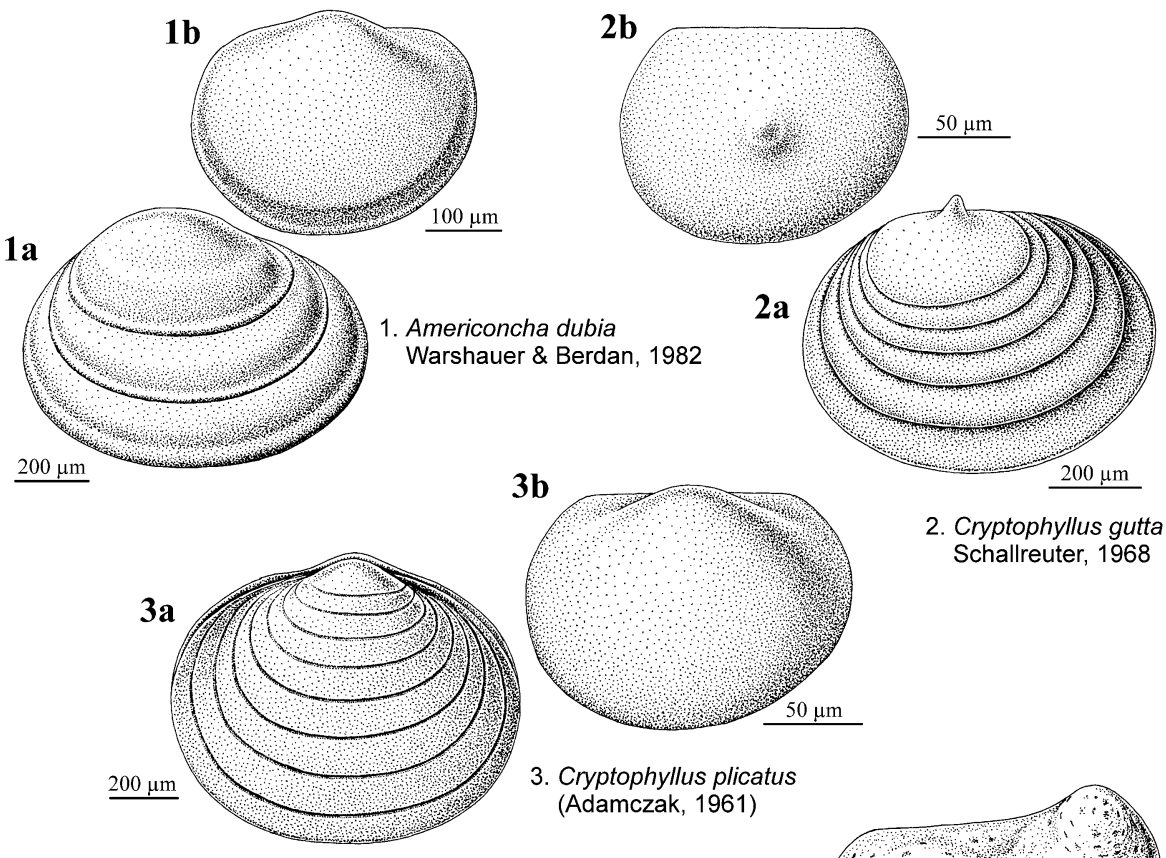

${ }^{3 b}$

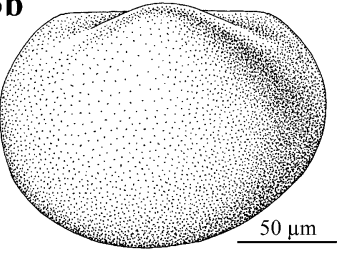

3. Cryptophyllus plicatus (Adamczak, 1961)
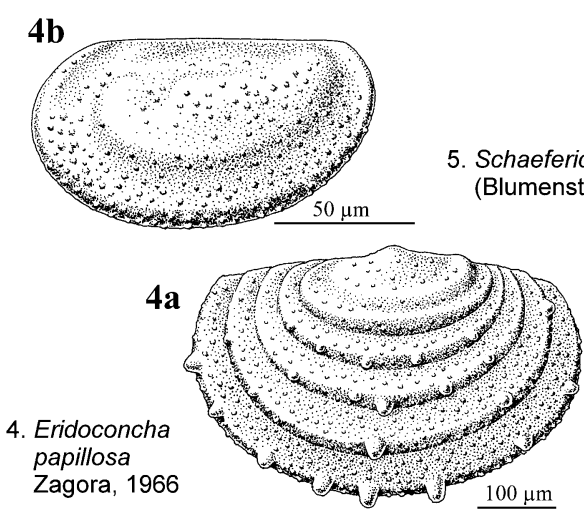

2. Cryptophyllus gutta Schallreuter, 1968
5. Schaefericoncha cf dorsospina (Blumenstengel, 1997)

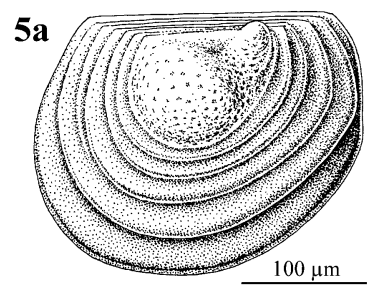

exfoliated layers to those in some ostracods (e.g. Matern, 1929; Harris, 1931, 1957; Bassler \& Kellett, 1934; Keenan, 1951; Levinson, 1950, 1951, 1961; Egorov, 1954; Jaanusson, 1957; Rome \& Goreux, 1960; Adamczak, 1961; Jones, 1962; Zagora, 1966; Schallreuter, 1968, 1977, 1987, 1995; Warshauer \& Berdan, 1982; Abushik, 1990; Whatley et al., 1993; Becker et al., 2004; Hoare \& Merrill, 2004; Becker \& Braun, 2007). Adamczak (1961) established the new suborder Eridostraca for such multilayered taxa as the Eridoconchinae Henningsmoen, 1953. Becker \& Sanchez de Posada (1977) raised the Eridostraca to Order rank, and subsequently the name was corrected to Eridocopida (Abushik, 1990).
In the present study, multilayered aberrant ostracods are considered to belong to the suborder Eridostracina within the Palaeocopida; their affinities are, however, still open to discussion.

Four eridostracine genera have been described; Eridoconcha Ulrich \& Bassler, 1923, Cryptophyllus Levinson, 1951, Schaefericoncha Schallreuter, 1987 and Leptoderos Hoare \& Merrill, 2004. Two other genera, Pygoconcha Schallreuter, 1968 and Americoncha Schallreuter, 1968, are questionably assigned to the group. They are grouped in three families, Eridoconchidae Henningsmoen, 1953, Cryptophyllidae Adamczak, 1961 (=? Rhabdostichidae Rusconi, 1954) and Schaefericonchidae Schallreuter, 1987. The families 
Conchoprimitiidae Henningsmoen, 1953 and Schmidtellidae Neckaja, 1966 are also considered by some authors (e.g. Schallreuter, 1968, 1978, 1993; Whatley et al., 1993; Tinn \& Meidla, 2004) to be Eridostracina.

The systematics of the eridostracines is highly speculative due to the limited number of diagnostic characters, including the character of the growth band ornamentation and the number of accumulated exuviae. The complete separation of the retained layers of the cuticle was noted by Rome \& Goreux (1960) in Late Devonian (Strunian) Cryptophyllus material and by Schallreuter (1977) in the Late Ordovician Cryptophyllus gutta Schallreuter, 1968. The separation of the valves of the carapace at the dorsal margin is a characteristic feature of the Ostracoda (Hartmann, 1963).

The suggested Cambrian ancestors of the "conchostracans', eridostracines and ostracods, such as Fordilla and similar genera (see Adamczak, 1961; Kobayashi, 1972), were recently considered to be Bivalvia (see Schneider, 2001). Silurian species from Podolia, Ukraine, recognized by Adamczak (1961) as members of the 'Conchostraca', were previously placed in the Eridostracina (Krandijevsky, 1958).

Several authors suggested that Eridostracina represent extinct marine Branchiopoda (Conchostraca) (Schmidt, 1941; Hartmann, 1963; Le Fevre, 1963; Gorak, 1966; Jones, 1968; Adamczak, 1976; Díaz Saravia \& Jones, 1999), based on the similarity of the multilayered carapace and the presence of 'growth lines' on the carapace to those in the spinicaudatans. According to Adamczak (1976, p. 292), the Eridoconchidae and Cryptophyllidae should be classified as phyllopods, 'because their carapace morphology shows essential similarities to the Conchostraca (many-layered carapace with the symmetry plane between the valves)'. Similarly, Wilson (1956) suggested that Rhabdostichus is a member of the poorly known Palaeozoic branchiopods. Langer (1973) believed that cryptophyllids and eridoconchids are neither ostracods nor conchostracans and represent a yet 'unknown' group.

Levinson's (1951) definition of eridostracine genera was based on the pattern of ornamentation of the growth line interspace. Adamczak (1961) defined Eridoconcha and Cryptophyllus based on the number of retained exuviae; numerous authors, however, considered the number of layers as an unstable character and refuted Adamczak's definition.

\section{Materials and methods}

Specimens of Cryptophyllus socialis (Eichwald, 1860) from the Upper Devonian (lower Famennian, Zadonsk Horizon) of the Kamenka section, Central Devonian Field (Voronezh region), Russia, were collected by Elena Sokiran (2002, 2003). The material comprises about 700 isolated valves and thousands of specimens preserved on slab surfaces and in thin sections (Fig. 3(1)). The external surfaces of the specimens are slightly abraded, and the carapaces are disarticulated, suggesting low-energy transport.

Samples from the Famennian of Russia were macerated in Glauber's salt $\left(\mathrm{Na}_{2} \mathrm{SO}_{4}\right)$ to produce exfoliated surfaces of the exuviae. For SEM observations, the specimens were coated with carbon and platinum. In order to evaluate the structure of the shells, thin sections were made and examined in transmitted light. For SEM study of the shell structure, a rock sample was sectioned, polished and subsequently etched with 'Mutvei's solution' (Schöne et al., 2005) for $1 \mathrm{~min}$.

Specimens of Cryptophyllus plicatus (Adamczak, 1961), Eridoconcha papillosa Zagora, 1966, Eridoconcha granulifera Adamczak, 1961 and Schaefericoncha dorsospina (Blumenstengel, 1997) have also been investigated. The material of C. plicatus, E. papillosa and $E$. granulifera from the Emsian and Eifelian, Lower and Middle Devonian of the Holy Cross Mountains, Poland, is from the collection of Franciszek Adamczak (ZPAL O.XLI) and additional specimens of E. granulifera derive from the author's collections. Specimens of $S$. dorsospina from the Upper Devonian of northwestern Poland were collected by Barbara Żbikowska (Polish Geological Institute, Warsaw).

The material is housed in the Institute of Palaeobiology, Polish Academy of Sciences in Warsaw (ZPAL O).

\section{Results}

Retention of moults

The hard exoskeleton of crustaceans is in most species mineralized with calcium carbonate, preventing continuous growth and development of the animal. Therefore, crustaceans shed their old exoskeleton periodically and form a new, larger exoskeleton. This moulting process is facilitated by complex hormone 

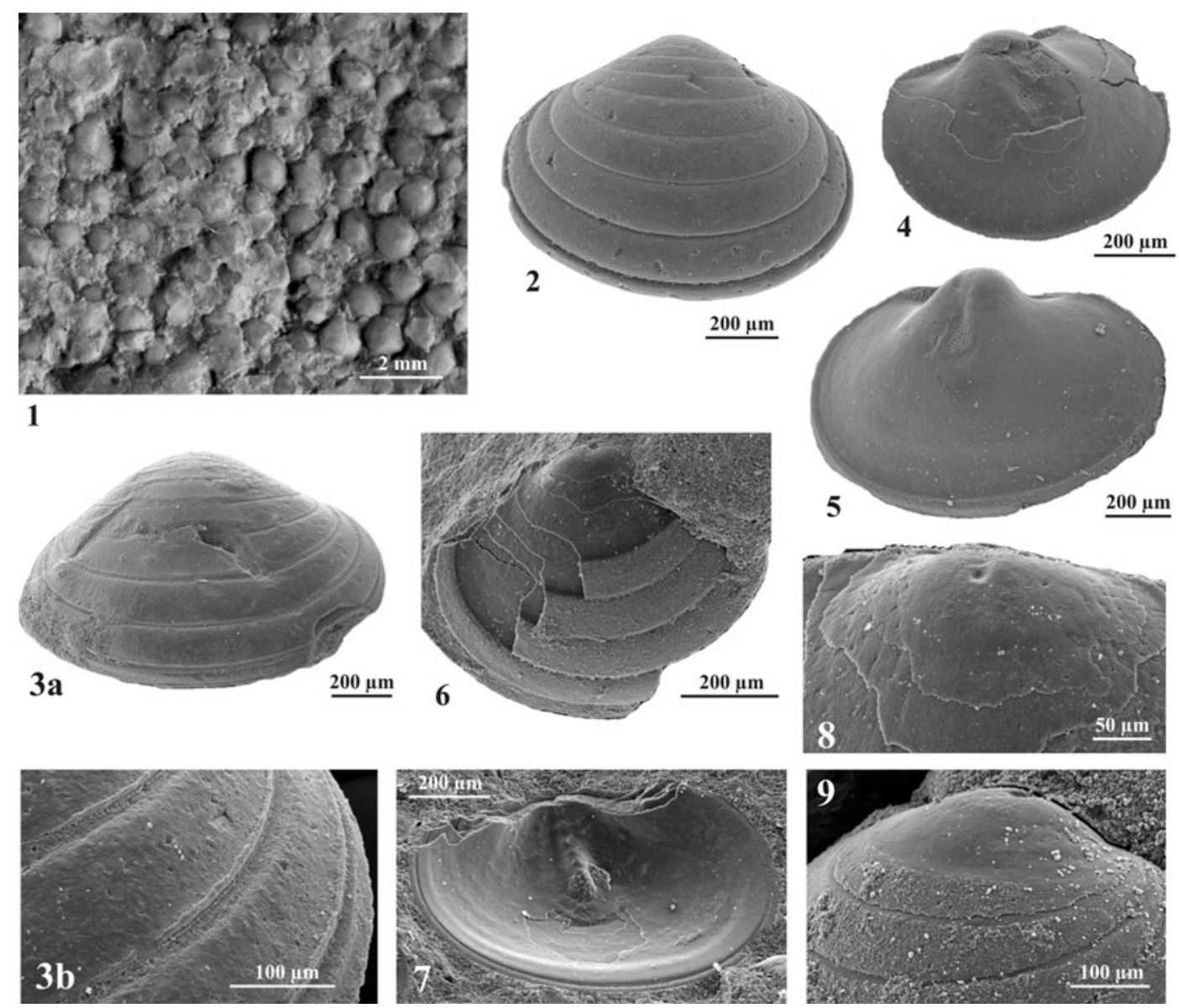

Fig. 3 Cryptophyllus socialis (Eichwald, 1860), Late Devonian (Early Famennian, Zadonsk Horizon), Kamenka section, Voronezh region, Russia. 1 Part of slab showing concentration of valves on the bedding plane by $C$. socialis. $2 \mathrm{RV}$, ext., lat. (ZPAL O.59/288). 3a, RV, ext., obl. ven.; 3b, close-up of growth lines (ZPAL O.59/286). $4 \mathrm{RV}$ of late instar, layers of more juvenile stages are exfoliated (ZPAL O.59/224). $5 \mathrm{RV}$ of adult stage, all juvenile shells are exfoliated (ZPAL O.59/238). $6 \mathrm{LV}$, ext. lat., illustrating layered nature of carapace,

control (steroid moulting hormone, neuropeptide moult-inhibiting hormone) (see Hartnoll, 2001) and many genes are involved in the formation of the new cuticle (e.g. Kuballa et al., 2007).

The moulting process in crustaceans has been divided into four stages: $\mathrm{A}$ and $\mathrm{B}$ (postmoult), C (intermoult), D (premoult) and E (ecdysis) (Drach, 1939). These stages are divided into sub-stages.

\section{Moult retention in eridostracines/ostracods}

The eridostracines grow by moulting, as with all other crustaceans, but retain each carapace instead of exfoliation along antero-central region is significant (ZPAL O.59/298). $7 \mathrm{LV}$, int. showing internal ridge, AMS and Fr.; a row of tubercles on the internal ridge marks of the AMS belonging to earlier exuviae (ZPAL O. 59/257). $8 \mathrm{RV}$, detailed view of the dorsal region of early juvenile stage showing adductorial pit (ZPAL O.59/219). 9 LV, ext., obl., detailed view of dorsal region of early juvenile stage, showing adductorial pit (ZPAL O.59/232). For abbreviations, see caption of Fig. 1

shedding them. Therefore, the carapace comprises several accumulated exuviae that gradually increase in size. Consequently, the free margin area of the newly deposited cuticle exceeds that of the previous instar and is visible on the external surface as a concentric 'growth band'. Successive growth bands are separated by grooves (growth lines) and gradually increase in height (Figs. 1, 2, 3, 4). In some eridostracine specimens, the most ventral growth band is narrower than in the preceding exuviae and this shell probably represents the adult stage. The carapace of the eridostracines is, however, much thinner in the ventral margin area and the terminal 
growth bands are often not preserved. The highest number of 15 valves underlying one another has been recognized in Cryptophyllus sp. 18 of Becker \& Bless (1974), from the upper Famennian to the lower Tournaisian of the Ardenno-Rhenish Massif (Western and Middle Europe), 14 of which are juvenile stages. In Cryptophyllus socialis, up to 13 valves may occur by the adult stage (Fig. 3(2, 3)).

Jones (1962) noted a maximum of 13 instars in Cryptophyllus diatropus Jones, 1962 from the Lower Carboniferous of Australia. There are 11 accumulated exuviae in Cryptophyllus sinsinensis Casier \& Devleeschouwer, 1995 from the lower Famennian (triangularis Biozone) of the Dinant Basin, Belgium. Cryptophyllus sinsinensis appears closely related or even conspecific with $C$. socialis. Up to 11 exuviae have been generally distinguished in the carapaces of Eridoconcha species (Harris, 1957; Adamczak, 1961). Seven juvenile stages were documented (Schallreuter, 1987, 1995) in Schaefericoncha theatri Schallreuter, 1987 from the lower Silurian (Llandovery-Wenlock) of Westphalia, Germany. Six juvenile stages occur in Schaefericoncha dorsospina, including the first juvenile valve.

Up to three instars may be retained in Americoncha and Pygoconcha (Schallreuter, 1968, 1987; Warshauer \& Berdan, 1982), thus their taxonomic position is not clear. In Leptoderos arytaina Hoare \& Merrill, 2004 from the Pennsylvanian (Morrowan) of Texas, two or three exuviae of the late instars are attached, while all exuviae of small instars have been exfoliated (Hoare \& Merrill, 2004, Fig. 6(40-46)).

Moult retention occasionally occurs also in other palaeocopid ostracods. Specimens of the Ordovician Conchoprimitia (e.g. C. tallinnensis Öpik, 1937; C. deminuta Öpik, 1937; C.? conchoidea (Hadding, 1913); C. sp. of Tinn \& Meidla, 2004) retain the cuticle of their carapace at one to three late moults; the weak furrow which represents the retention mark is sometimes also present (Hadding, 1913; Öpik, 1937; Henningsmoen, 1953; Jaanusson, 1957; Tinn \& Meidla, 2004). The Conchoprimitidae were regarded by some authors as members of the Eridostracina (e.g. Schallreuter, 1993; Whatley et al., 1993; Tinn \& Meidla, 2004).

A number of specimens of the kirkbyoidean palaeocopid Ectodemites plummeri Cooper, 1946 from the Pennsylvanian of Texas have two of the same valves intact (Cooper, 1945), as does the kirkbyoidean
Amphissites tener omphalotus Becker, 1964 from the Middle Devonian of northern Eifel, Germany (Becker, 1964, pl. 12/4). Martinsson (1962) described the retention of one exuviae in the beyrichioidean Craspedobolbina (Mitrobeyrichia) clavata (Kolmodin, 1869) from the Silurian of Gotland. Hoare \& Merrill (2004) illustrated specimens of the leperditellid Moorites tumidus Hoare \& Merrill, 2004 from the Pennsylvanian of Texas, with up to three valves intact.

Accidental moult retention was also noted in the beyrichioidean Kozlowskiella kozlowskii (Přibyl, 1953) (Adamczak, 1958, p. 79; Fig. 1(8)). In all Palaeozoic multilayered species, the exuviae are attached along the dorsal margin.

The aberrant platycopid ostracod species Platella bosqueti (van Veen, 1932) from the Upper Cretaceous of South Limburg, The Netherlands, showed moult retention. In this species, however, the retention area (point of retention) is located along the postero-ventral margin (Jones, 2003).

Keenan (1951) and Levinson (1951, p. 555), and others, interpreted the multilayered carapace of Cryptophyllus and Eridoconcha 'as being due to incomplete shedding of moults accompanied by later cementation'. According to Levinson (1951, p. 553), the accumulation of exuviae is a specialized adaptation of generic importance.

Adamczak (1961) interpreted the multilayered condition of the carapaces as an early stage in the development of the moulting process and suggested that the number of retained layers decreases during the evolution of cryptophyllids and eridoconchids, leading to the development of the unilayered carapace of the 'ostracoid type'. It should be noted that the reduction of the number of retained stages during the evolution of eridostracines is not supported by the nature of mid- and late-Palaeozoic carapaces.

Jones (1962, p. 18) considered the Cryptophyllidae and Eridoconchidae as a specialized aberrant group of the Ostracoda. In subsequent papers, Jones (1968) and Adamczak (1976) suggested that they are members of the Branchiopoda, but they did not give additional evidence for such assignment.

\section{Moult retention in other Crustacea}

Retention of moults and the presence of growth lines on the external surface of the carapaces occur in other groups of fossil and living bivalved crustaceans: in 

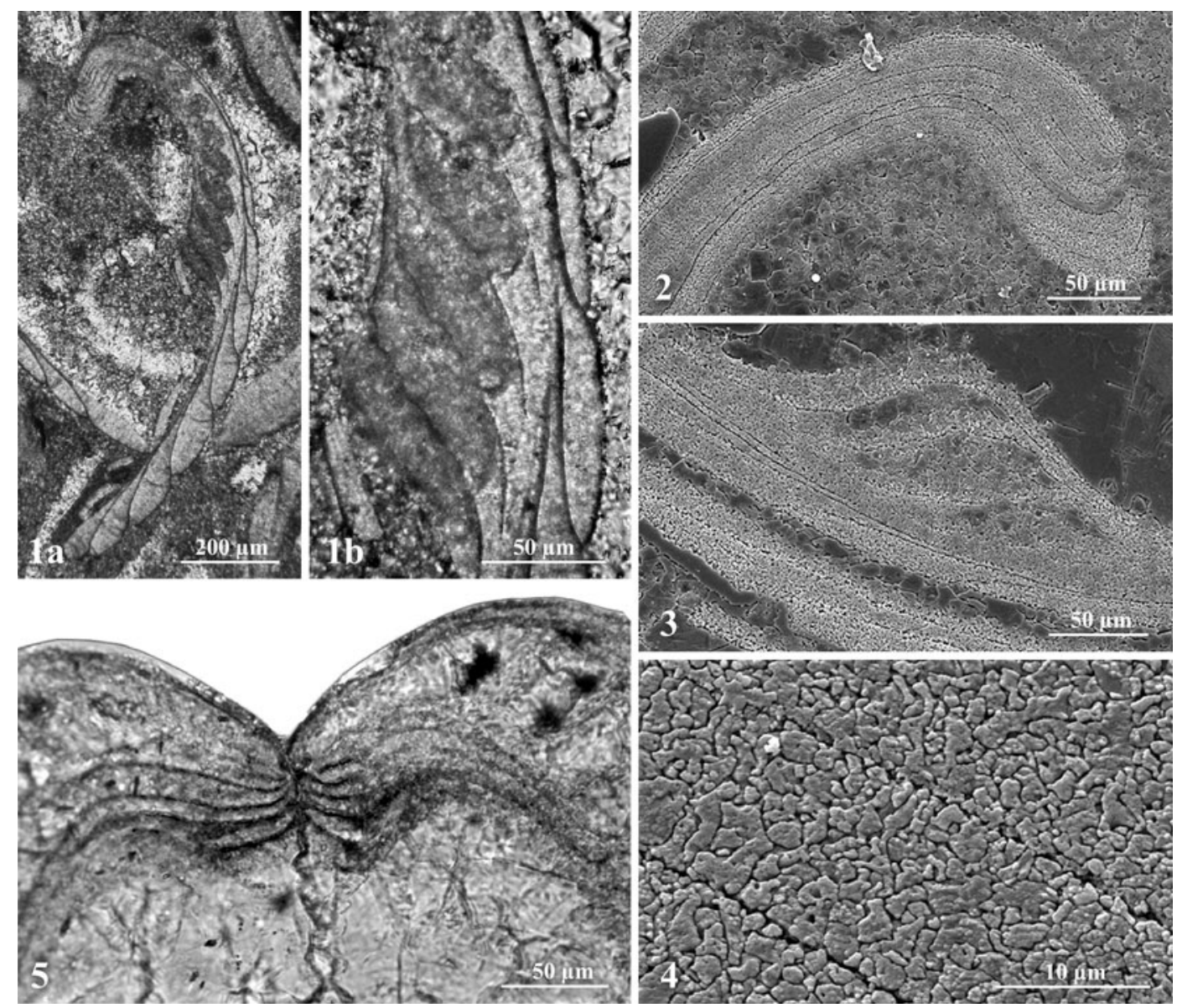

Fig. 4 1-4 Cryptophyllus socialis (Eichwald, 1860), Late Devonian (Early Famennian, Zadonsk Horizon), Kamenka section, Voronezh region, Russia. 1 Light micrographs of transverse thin section, and close-up of interlayer chambers area (ZPAL O.59/400). 2 SEM micrograph of transverse section showing dorsal region (ZPAL O.59/175). 3 SEM micrograph of transverse section showing interlayer chambers

the all Spinicaudata (Conchostraca) and also in two cladoceran genera, Monospilus and Ilyocryptus (see Olesen, 1998, 2000).

\section{Determinate and indeterminate growth}

The moulting process ceases definitively in some crustaceans (terminal anecdysis) and the growth is determinate. If there is no terminal anecdysis, the growth is indeterminate and continues indefinitely (see Hartnoll, 2001 for review).

The Ostracoda have a determinate growth with up to nine instars, including the mature (adult) animal. area (ZPAL O.59/182). 4 Close-up of transverse section showing microstructure of layers (ZPAL O.59/184). 5 Cryptophyllus plicatus (Adamczak, 1961), Early Devonian (Emsian, Grzegorzowice Formation), Grzegorzowice, Holy Cross Mts., Poland. Light micrographs of transverse thin section showing dorsal region and hinge structures of LV and RV placed obliquely in relation to one another (after Adamczak, 1961)

Martinsson's (1956) analysis of the ontogeny of ostracods from the Silurian of Gotland, Sweden, showed that the growth factors of some species are in accordance with Brooks's law, with a linear growth factor of about 1.26. The growth factor is lower in the case of the last moult.

It seems likely that in cryptophyllids and eridoconchids, the growth is determinate and the mature instar is represented by one valve with the growth band much narrower than the previous (see also Jones, 1962, p. 16). The interspaces between the growth lines of juvenile stages gradually increase in height, and their size appears independent of environmental conditions. 
In contrast, the growth in Branchiopoda is indefinite (see Hartnoll, 2001). Living spinicaudatans undergo ecdysis approximately every 1 to 3 days, and the number of growth lines and growth-line spacing is controlled by environmental conditions such as temperature and food availability (Thiéry, 1996).

Besides hormone and gene control of the moulting process, external factors have substantial influence upon growth. The most important factors include temperature, food concentration, salinity and light conditions, and parasitism (see Hartnoll, 2001; Keyser, 2005; Anger, 2006).

The influence of environmental factors such as pollution on the disruption of hormonal pathways in crustaceans has long been noted (e.g. LeBlanc, 2007). Aberrations in growth, metamorphosis, reproductive maturation and sex determination may occur in animals living in polluted environments. If exposure to such environments continues for a long time, genetically modified populations of organisms that can tolerate such conditions may appear (LeBlanc, 2007).

The mass occurrence of cryptophyllids is associated with shallow-marine marginal environments (Egorov, 1954; Jones, 1962; Casier \& Devleeschouwer, 1995; Sokiran, 2002). Such settings are characterized by abnormal salinity and temperature conditions.

Some Cryptophyllus and Eridoconcha species have more juvenile stages compared to Recent ostracods. This may indicate that the number of juvenile instars has been reduced during ostracod evolution. It is also possible that the prolongation of ontogeny in eridostracines and moult retention is due to the disruption of the hormonal pathway caused by environmental conditions (temperature and salinity), possibly due to narrower salinity tolerances. Additionally, the retention of extremely thin valves in settings with low calcium content may strengthen the construction of the carapace.

The influence of the environment on the construction of the ostracod carapace has been documented in the Recent ostracod Cyprideis torosa (Jones, 1850) in the form of the presence of nodes in certain parts of the shell. The number of noded specimens increases with falling salinity values. The noding is caused by the disruption of the osmoregulation process during moulting in low salinity waters and reduction of the flexibility of desmosomes, their rupture during moulting and the development of nodes in the still flexible cuticle (Keyser, 2005).
Shell structure

The cuticle of the valve of living ostracods comprises two parts: an outer lamella and an inner lamella. The outer lamella is divided into three sub-layers, the epicuticle, the procuticle (divided into exo- and endocuticle) and a membranous layer. The exo- and endocuticles are usually calcified, while the epicuticle and membranous layer remain uncalcified. The inner lamella cuticle is thin, flexible and uncalcified except for the much thicker marginal part near the free margin of the carapace. The outer and inner lamella of the cuticle are secreted by the outer and inner epidermal cells. The ostracod carapace cuticle is mineralized with low magnesium calcium carbonate in the form of calcite. In recent podocopids, small calcite crystals are embedded in the organic matrix. During moulting, calcium is concentrated in the outer epidermal cells in the form of granules composed of calcium phosphate. After expulsion into the cuticular layer, calcium phosphate is transformed into amorphous calcium carbonate, which is altered later into crystalline calcite (Keyser, 1995; Keyser \& Walter, 2004). Several authors have described the cuticular ultrastructure of Recent ostracods (e.g. Müller, 1894; Kesling, 1951; Jørgensen, 1970; Sylvester-Bradley \& Benson, 1971; Bate \& East, 1972; Langer, 1973; Bate \& Sheppard, 1982; Okada, 1982a, b; Rosenfeld, 1982; Keyser, 1990, 1995; Keyser \& Walter, 2004).

The shell structure of Recent and fossil spinicaudatans does not differ from that of other crustaceans; their cuticle is, however, weakly biomineralized and contains a chitin-phosphate complex (Martin, 1992). Rieder et al. (1984) published SEM photographs with cross-sections of the fractured shell surface in the Recent Leptestheria species. The multilayered structure of the carapace was observed in thin sections of the spinicaudatan Laxitextella sp. from the Triassic of Krasiejów, Poland (Olempska, 2004).

In thin sections and SEM images, Cryptophyllus socialis shows only one distinct calcified layer of each exuviae (Fig. 4(1-4)). Under a light microscope, the calcite layers appear amorphous (Fig. 4(1a, b)). As observed in transverse sections of the etched specimens, the shell of each attached exuviae is composed of fine irregular calcite crystals (Fig. 4(2-4)) (see also Poltnig, 1983). The size of the crystals is ca. $0.5-3 \mu \mathrm{m}$. They vary in outline, from angular to slightly rounded, and have no uniform orientation (Fig. 4(4)). The 
exocuticle and endocuticle layers were not recognizable on the basis of the crystallite size or laminated texture. Organic frameworks, remains of the epicuticle and the membranous layer, were not observed in the shell layers. The size of crystals is uniform between the successive exuviae.

The boundaries between the exuviae are generally sharp; the layers are, however, closely adherent. The thickness of each layer at the median area decreases with the increasing thickness of the layer at the marginal area (growth band) (Fig. 4(1a, b)). The multi-layered valve of the adult specimens of $C$. socialis with 13 accumulated exuviae has a thickness of 40-50 $\mu \mathrm{m}$ in the median part below the internal ridge. The maximum thicknesses occur in the dorsal area, where all the shells of the exuviae are accumulated. Impregnation of the external surface of $C$. socialis by inorganic salts (ore-deposits, iron compounds) may occur.

EDX analyses show that in the subsequent exuviae of the same specimens, the carapace weight comprises $98-99 \%$ of combined $\mathrm{Ca}, \mathrm{C}$ and $\mathrm{O}$ and small amounts of $\mathrm{Mg}$; elements such as $\mathrm{Fe}, \mathrm{Ni}$ and $\mathrm{Mn}$ are almost absent in the carapace.

Morphological features of the carapace

Cryptophyllids and eridoconchids are relatively conservative in general body features such as the small sizes of adults, typically not exceeding $1.5 \mathrm{~mm}$ in length, sub-ovate to sub-triangular outline in lateral view and long and straight dorsal margins. The carapaces are almost equivalved; no overlapping of valves was noted. The umbo often projects above the hinge line. In some Cryptophyllus and Eridoconcha species, the naupliconch valve bears a posteriorly directed spine [C. gutta Schallreuter, 1968; C. conodus Schallreuter, 1999; C. magnus (Harris, 1931); C. nuculopsis Harris, 1957; E. simpsoni Harris, 1931].

Some species of Cryptophyllus [e.g. C. socialis (Eichwald, 1860); C. oboloides (Ulrich \& Bassler, 1923); C. sulcatus Levinson, 1951] and Eridoconcha [e.g. E. marginata (Ulrich, 1890); E. elegantula Keenan, 1951] exhibit a well-developed adductorial sulcus in later instars, which is hidden under the valves of earlier instars (Keenan, 1951; Levinson, 1951). This structure corresponds to a well-developed internal ridge (=sulcament; see Schallreuter, 1967).

In $C$. socialis, the deep ventral parts of the sulci, invaginated into the valve interior, form a series of solid interlayer chambers between the subsequent valves (Figs. 4(1a, b), 5). The chambers are filled with large calcite crystals (Fig. 4(3)). Adamczak (1961, p. 57, Figs. 1, 2; pl. 1/1-3) reported the occurrence of interlayer chambers in thin sections of C. plicatus and regarded them as hydrostatic organs. However, Adamczak did not recognize the presence of a median sulcus in Cryptophyllus. Apart from this, it seems that the probably in vivo air-filled interlayer chambers may function as such organs.

Figures 1 and 2 provide an overview of the valve shapes and ornamentation in some eridostracine species.

\section{External morphology}

The systematics of Cryptophyllus species is speculative in a number of cases because of the limited number of diagnostic characters (outline of the carapace and size ratios). The external surface of their valves consists of a succession of flat growth bands without ornamentation, separated by small narrow grooves (Figs. 1, 2, 3). An anteriorly located distinct umbo usually strongly projects above the hinge line. The anterior, posterior and ventral margins are sharply rounded. The $C$. socialis group is characterized by flat growth bands without ornamentation (Fig. 3(2-9)). In the later growth stages of $C$. socialis, a long sulcus is developed with a negative pattern of the adductor muscle scar at its termination. A row of small depressions is developed inside the sulcus, indicating the position of the adductor muscle scars of the earlier exuviae (Fig. 6(7)). A small adductorial pit is developed in early stages (Fig. 3(8, 9)).

Eridoconcha differs from Cryptophyllus in the distinct ornamentation on the interspace between the growth lines (Figs. 1(1-3), 2(4)). Usually the growth bands bear elevated concentric ridges, spines and tubercles. The growth bands are separated by U-shaped grooves.

Schaefericoncha has a preplete outline and a long, straight hinge line. The long and wide adductorial sulcus is developed in the late instars of $S$. theatri (Schallreuter, 1995, Fig. 10A/3). The shape of $S$. dorsospina and ornamentation of the first larval valve resembles that of some beyrichioideans, namely Kozlowskiella species, in having a long hinge line and a similar outline. In $S$. dorsospina, six layers of cuticle are preserved (Figs. 1(5), 2(5)). 
(a)

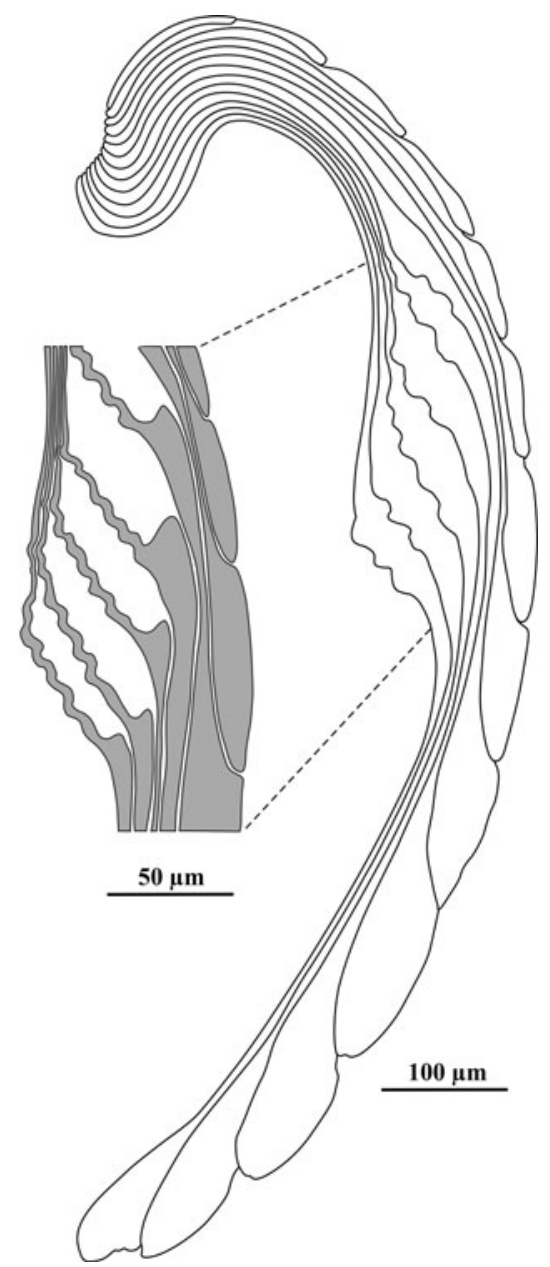

Fig. 5 Cryptophyllus socialis (Eichwald, 1860). a Schematic drawing of transverse section to show the layered nature of the valve; $\mathbf{b}$ close-up of AMS and interlayer chambers area

\section{Sexual dimorphism Harris (1957) considered} Eridoconcha simpsoni Harris, 1931 to demonstrate sex-related shell dimorphism, with the supposed males being more elongate than the supposed females. Levinson (1951) suggested the presence of similarly manifested sexual dimorphism in Eridoconcha and Cryptophyllus.

Elongated and more ovate specimens occur in Eridoconcha papillosa from the Middle Devonian of the Holy Cross Mts., Poland, and also in C. socialis. However, these species show intraspecific variations of the carapace shape and it is not clear whether the differences in size and outline reflect sexual dimorphism. Domiciliar dimorphism has not been recognized. Williams \& Jones (1990) have questioned the presence of sexual dimorphism in E. simpsoni.
Internal morphology

Free margin In $C$. socialis, the marginal infold (calcified inner lamella) is not developed. Ventral contact structures such as the contact groove and corresponding list are absent.

Muscle scar pattern Adductor muscle scars in living crustaceans represent the attachment points of the adductor muscles to the calcified outer lamella. The adductor muscles extend from valve to valve and they function in closing the valves. The morphology of the adductor muscle scars is of great taxonomic significance in both Recent and fossil ostracods.

The frontal, mandibular and dorsal muscle scars represent the attachment points of different muscles of the appendages. The large number of dorsal muscle scars is a common pattern in fossil and Recent podocopid ostracods. The frontal scar occurs in the front of the dorsal part of the adductor muscle scar and is related to the mandibular muscles. The muscle scar pattern in living ostracods has been reviewed by numerous authors (e.g. Kesling, 1951; Andersson, 1974; Yamada \& Keyser, 2009 and many others).

In $C$. socialis, the adductor muscle scar is located in the sub-central area, on the top and sides of the ventral part of the internal ridge. The scar is developed as a circular cluster of individual scars (Figs. 3(7), 6(1, 2, 3a, 4), 7, 8(1a, 2)). In the late growth stages, the adductor muscle scar consists of 25-30 individual scars developed as semicircular or slightly elongated tubercles (Figs. 6(1b, 2, 3a), 7). The tubercle group is surrounded by smaller peripheral circular pits (Fig. 6(2)).

The present study shows that the number of individual scars in the adductor muscle scar of $C$. socialis is related to the growth stage, i.e. the number of scars and their dimensions increase from stage to stage.

The position of the adductor muscle scar slightly changes in relation to the anterior and posterior margins of the valve during ontogeny. In the adult stage, it is located slightly more anteriorly than in the previous instars. In the later stages of $C$. socialis, a long row of small tubercles indicating the position of the adductor muscle scars of earlier instars is visible on the surface of the internal ridge (Figs. 3(7), 6(1a, 2)). The adductor muscle scars are represented as counterparts by deep pits on the outside of the carapace 

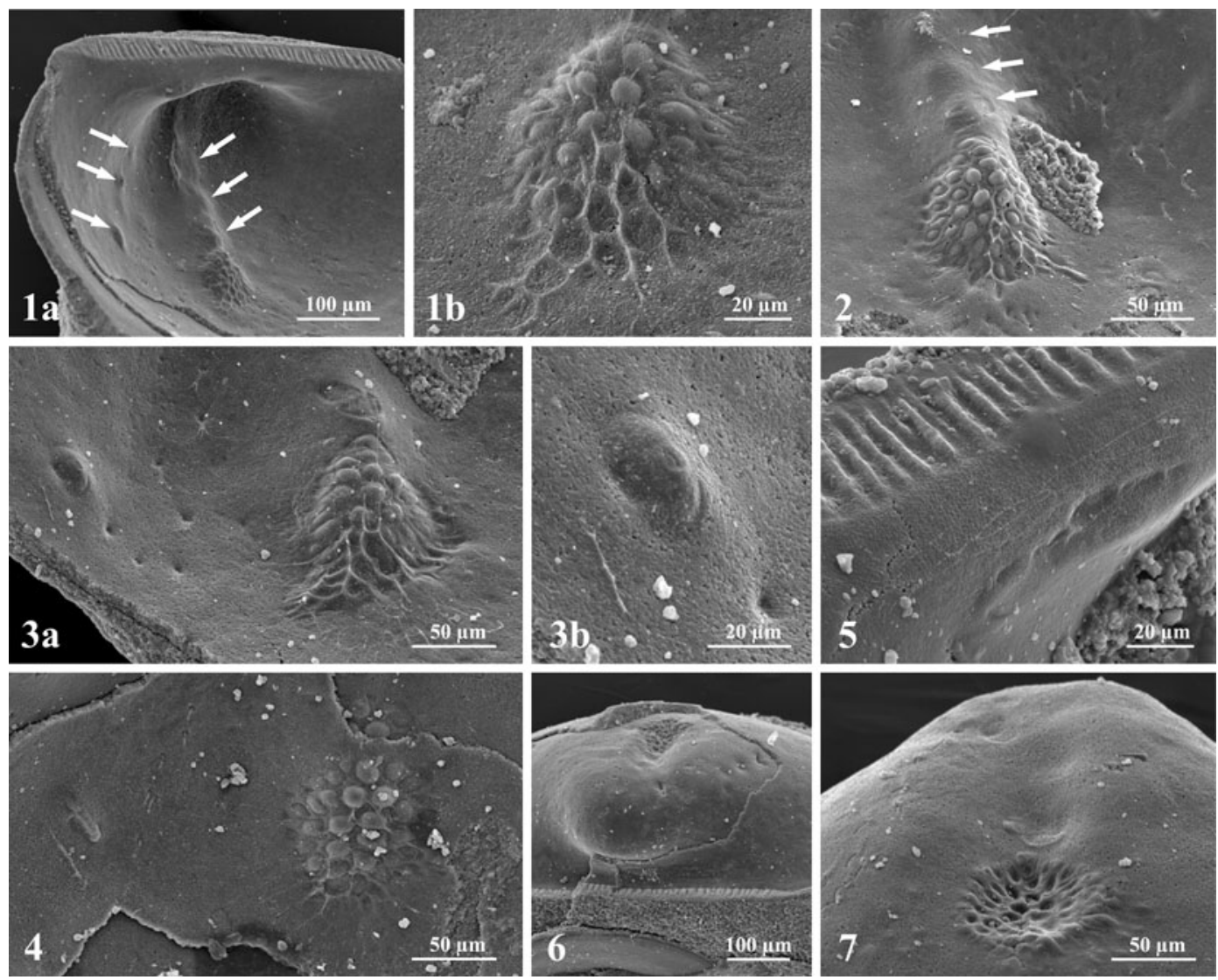

Fig. 6 Muscle scar pattern of Cryptophyllus socialis (Eichwald, 1860), Late Devonian (Early Famennian, Zadonsk Horizon), Kamenka section, Voronezh region, Russia. 1a RV of late instar, int. showing AMS and Fr.; scars of previous exuviae visible across several layers of cuticle, indicated by arrows; 1b close-up of AMS (ZPAL O.59/211). 2 LV, int., showing AMS; a row of small tubercles on internal ridge marks of the AMS belonging to earlier exuviae, indicated by arrows (ZPAL 0.59/257). 3a RV, int. showing AMS, ovate scar above

(Figs. 6(6, 7), 9(6)). A strong ovate dorsal scar that is more or less elongated towards the anterior and posterior margins occurs directly above the adductor muscle scar. This scar is subdivided into two parts by a barely distinct groove (Figs. 6(2, 3a), 7). A distinct frontal muscle scar, developed as an elongated tubercle, is located in front of the adductor muscle scar (Figs. 6(1a, 3a, 3b, 4), 7). The frontal scars are also visible as concave impressions on the external surfaces of the exuviae (Fig. 6(6)).

In some specimens of $C$. socialis, a row of frontal scars and a row of marks of the adductorial scars belonging to earlier exuviae can be observed across the AMS, and Fr.; 3b close-up of Fr. (ZPAL O.59/262). 4 RV, int., close-up of central muscle field area showing AMS and Fr.; AMS of previous instar partly preserved (ZPAL O.59/231). $5 \mathrm{RV}$, int., close-up of dorsal scars (ZPAL O.59/237). $6 \mathrm{LV}$, ext., dors., showing negative relief of AMS and Fr. (ZPAL O.59/226). $7 \mathrm{LV}$, ext. showing negative relief of AMS; a row of small depressions marks of AMS belonging to earlier exuviae (ZPAL O.59/251), For abbreviations, see caption of Fig. 1

several very thin shell layers of the previous exuviae (Fig. 6(1a)). The mandibular scar is not developed.

The dorsal region bears an array of small impressed dorsal scars located anteriorly in relation to the shell mid-length, parallel to the dorsal margin and below the hinge line (Figs. 6(5), 9(3)). In the adult stage number varies from 7 to 9 . The scars are visible on the external surface in slightly positive relief. There are no muscle scars in the posterior part of the carapace.

It is evident that the median sulcus and the corresponding internal ridge in $C$. socialis are of adductorial origin. The median sulcus and also the 


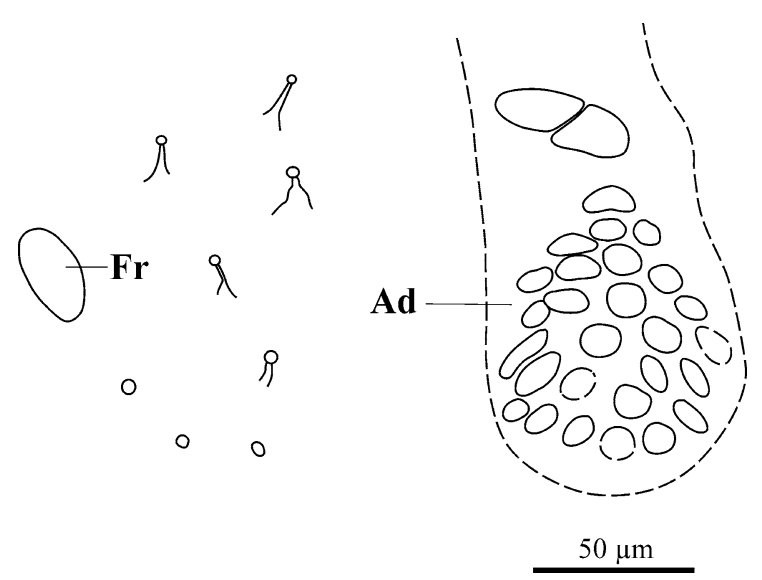

Fig. 7 Schematic drawing of central muscle field of Cryptophyllus socialis (Eichwald, 1860) (ZPAL O.59/262)

'negative pattern' of the muscle scars on the external surface developed due to the strain placed upon the freshly moulted non-calcified valves by the closing muscles. The deep ventral part of the sulcus implies strong muscle attachment, suggesting that the welldeveloped muscles control the adduction of the valves in adult forms of $C$. socialis.

The adductor muscle scar pattern of $C$. socialis is similar to that of some Palaeozoic palaeocopids and podocopids in having an aggregate of a few smaller scars. It is particularly similar to that in Healdianella specimens from the Carboniferous of Russia (Gramm, 1982). The 'healdiid' pattern of the adductor muscle scar is very common in Palaeozoic ostracods (Becker, 1996). Data on the central muscle field of Palaeozoic ostracods are still limited; information on the adductor muscle scar field in Palaeozoic ostracods was summarized Becker (1996, 2005). The Beyrichioidea (Palaeocopida) patterns of the muscle scars are relatively well known in Devonian and Early Carboniferous species (Olempska, 2008).

Very little is known about the adductor muscle scar of the eridostracines. Jones (1962, Fig. 6f, pl. 2/13) stated that the adductor muscle scar of Cryptophyllus platyogmus Jones, 1962 from the Lower Carboniferous (Viséan to possible Serpukhovian) of the Bonaparte Gulf Basin, Australia, comprises up to 50 individual scars, each one up to $13 \mu \mathrm{m}$ in diameter. In Eridoconcha sp. A from the Middle Devonian of Germany, Langer (1973, p. 36) noted the presence of the adductor muscle scar and figured it on one individual (Langer, 1973, Fig. 21; pl. 10/6); however, the area of the adductor muscle scar is poorly visible in the illustration as a result of imperfect preservation and the reconstruction of the adductor muscle scar appears incorrect.

An adductor muscle scar developed as a group of small rounded scars is visible in specimens of Eridoconcha simpsoni Harris, 1931 from the Middle Ordovician of Oklahoma, USA (Williams \& Jones, 1990, pl. 17 (16)/3). The structure is not discussed by the authors.

In spinicaudatan (conchostracan) branchiopods, the carapace is closed by adductorial muscles developed in the head region (see Thiéry, 1996).

Cell-like structures In living ostracods, the cells of the outer epidermal layer are the place where the calcified outer lamella and the external ornamentation of ostracod shells are produced. In the Recent Bicornucythere bisanensis (Okubo, 1975), the outer epidermal cells are about $60 \mu \mathrm{m}$ long and about $10 \mu \mathrm{m}$ thick (Okada, 1982a, b).

The muscles in living ostracods are attached directly to the cuticle by specialized epidermal cells (Okada, 1983b). These cells (tendinal cells) are adhered to the cuticle by conical hemidesmosomes with intracuticular fibres (Okada, 1983b; Yamada \& Keyser, 2009).

In almost all exfoliated specimens of $C$. socialis, a fossilized remnant of the cell-like structure is preserved inside the interlayer chambers on the surface of the adductor muscle attachment area (Fig. 8). The cell-like structures are preserved in three-dimensions (3D) and some are partly collapsed inward. They are polygonal in shape, $10-15 \mu \mathrm{m}$ in diameter, and separated from one another only by the thin cell membrane walls. The circular depressions occur in cells which lie directly on the muscle scar tubercles (Fig. 8(1c, d)). At high magnifications, the area of the adductor muscle scars displays a network of very thin and long fibres that cover the adductor muscle scar area (Fig. 8(1a)). Traces of polygonal cell boundaries are present just below the adductor muscle scar (Fig. 8(2,3)). It seems likely that the 3D cell-like structures possessing the circular depressions represent the outer epidermal cells (tendinal cells?) which connect the muscle fibres to the cuticle.

In addition, some specimens of $C$. socialis bear imprints of polygonal cell boundaries on the inner surface of the shell, seen as differences in the 

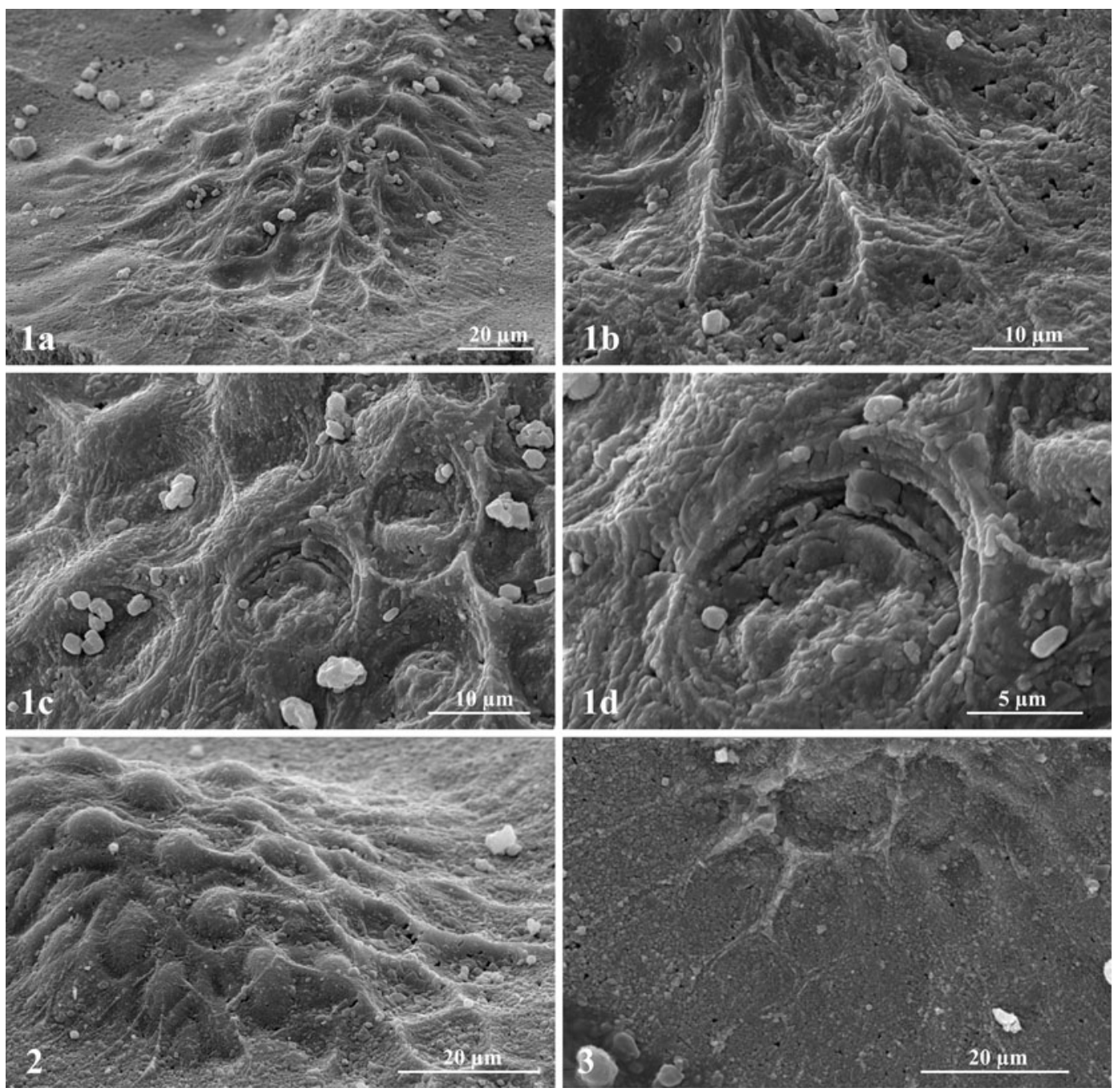

Fig. 8 Cell-like structures of Cryptophyllus socialis (Eichwald, 1860), Late Devonian (Early Famennian, Zadonsk Horizon), Kamenka section, Voronezh region, Russia. 1a LV, int., showing AMS and polygonal cell-like structures, $\mathbf{1 b}$ closeup of cell-like structures placed outside the AMS, 1c close-up of cell-like structures placed on the adductor muscle tubercles,

modification of the crystallographic orientation of the crystal units (Fig. 13(1b)). It seems likely that these structures correspond to the pattern of the boundaries between the outer epidermal cells similarly as in Recent podocopan ostracods.

The 3D preservation of the cell-like structures on the adductor muscle scar area of $C$. socialis was probably facilitated by the rapid closure of the interlayer chambers during the moulting process and their early mineralization. 1d close-up of cell-like structure restricted to the muscle scar tubercles (ZPAL O.59/254). 2 RV, int., showing cell-like structures placed partly on AMS, and partly below AMS (ZPAL O.59/211). $3 \mathrm{RV}$, int., close-up of cell-like structures below the AMS, polygonal cell boundaries only preserved (ZPAL 0.59/231). For abbreviations, see caption of Fig. 1

Hinge structure In living podocopid ostracods, the hinge structure consists of an uncalcified cuticle (ligament) and a calcified cuticle (hingement) developed along the attached dorsal margin inside both valves. The ligament comprises a large number of chitin fibres and is part of a continuous cuticular sheet (see Yamada, 2007a, b). The hingement in ostracods is composed of interlocking bars and grooves, crenulated sculptures or teeth and sockets, and can operate as a pivot. Yamada (2007a) discussed 

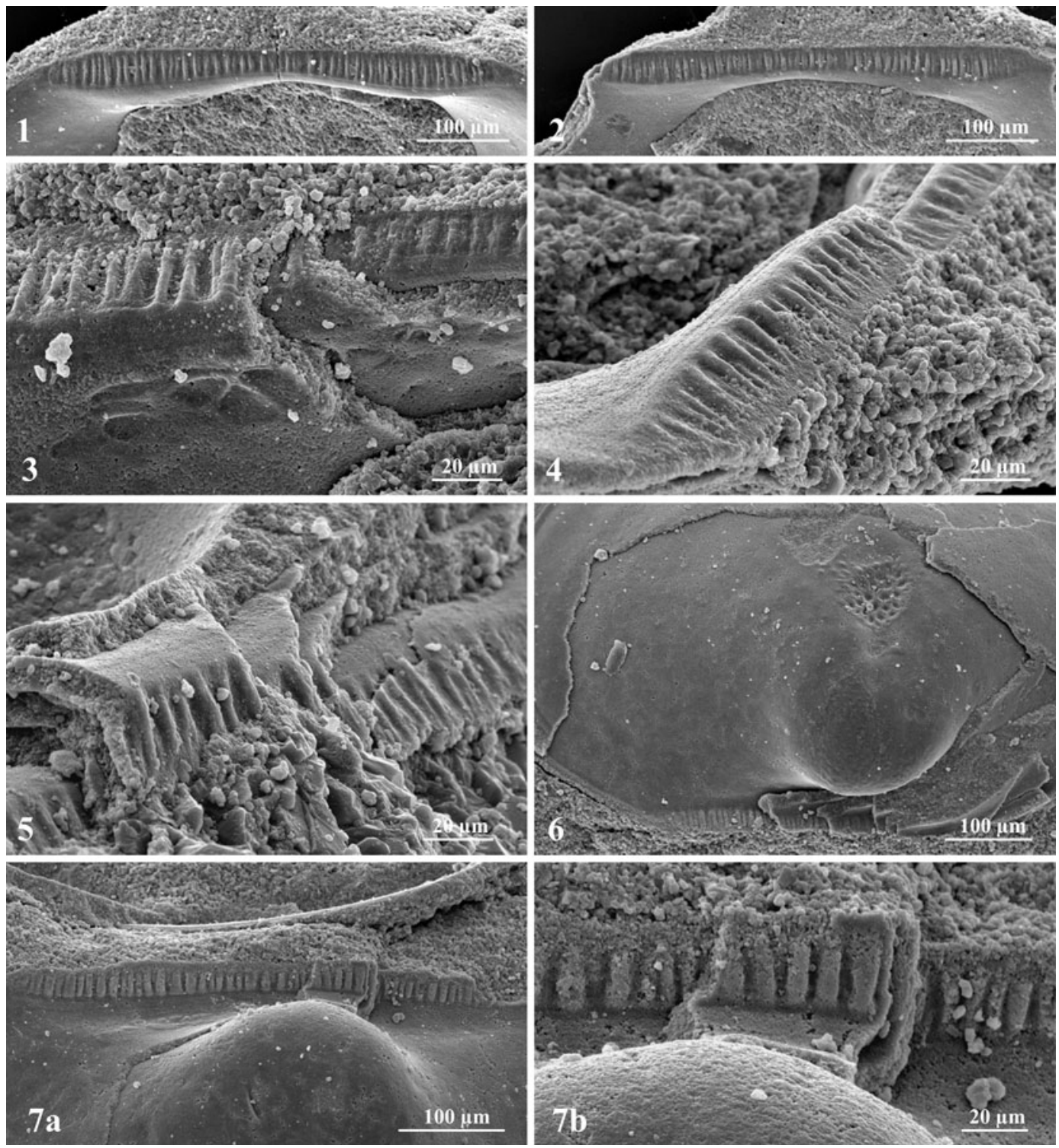

Fig. 9 Hingements of Cryptophyllus socialis (Eichwald, 1860), Late Devonian (Early Famennian, Zadonsk Horizon), Kamenka section, Voronezh region, Russia. $1 \mathrm{RV}$, int., crenulated hingement (ZPAL O.59/221). 2 LV, int. crenulated hingement (ZPAL O.59/269). $3 \mathrm{RV}$, int., showing anterior part of hinge of three attached exuviae, dorsal scars visible below the hinge; $\mathbf{4}$ posterior part of hinge of two attached exuviae

(ZPAL O.59/250). 5 LV, int., dor., showing hinge structure of four exuviae (ZPAL O.59/256). $6 \mathrm{RV}$, int., dor., external imprints of hinge structure of five exuviae partly preserved (ZPAL O.59/245). 7a External imprint of hinge structure, partly preserved imprints of three exuviae, $7 \mathbf{b}$ close-up of $\mathbf{7 a}$ (ZPAL 0.59/226). For abbreviations, see caption of Fig. 1

in detail the formation of the hinge in the Recent podocopid ostracod Loxoconcha pulchra Ishizaki, 1968, and clearly documented that the formation of the hingement proceeds asynchronously in the two valves. The hingement of the right valve is formed first and functions as a mould for the left hingement.

Subsequently, they form a precise interdigitated structure (Yamada, 2007a).

In Recent spinicaudatans, the valves are joined dorsally by a simple fold, and no true hinge occurs (see Martin, 1992, p. 34). The hingement of C. socialis is developed along the dorsal margins of the right and left 


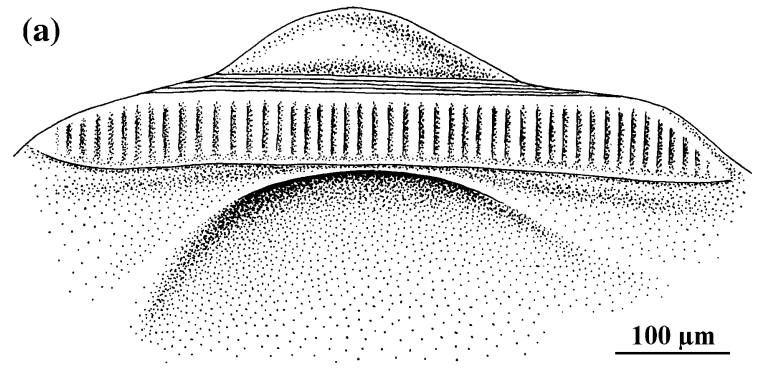

(b)

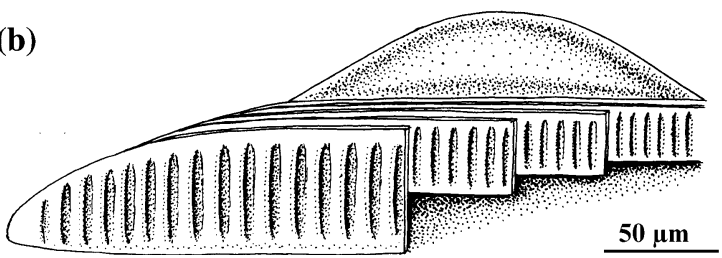

Fig. 10 Cryptophyllus socialis (Eichwald, 1860). a Schematic drawing of hingement, b close-up of hingement showing ventral shift of successive accumulated valves

valve in each retained exuviae (Figs. 9(1-5), 10). It consists of a crenulated list, which widens slightly in the anterior and posterior parts and narrows in the middle part, beneath the umbo. Along its entire length, the hingement is crossed by thin vertically elongate tiny crenulate. There are no significant differences between the adult and juvenile stages, except for the size and number of crenulate.

In $C$. socialis, the hingements of the right and left valve are developed similarly, without interlocking crenulated bars and grooves in the opposite valves (Fig. 9(1, 2)); such structure cannot operate as a pivot. The transverse thin section of Cryptophyllus plicatus (Adamczak, 1961) from the Middle Devonian of the Holy Cross Mountains, Poland (Adamczak, 1961, Fig. 1(2a); Fig. 4(5) herein), shows that the hingements of the right and left valves were not in contact when the carapace was closed but were placed obliquely in relation to one another. The valves were connected only along an extremely small area developed above the hingement.

The external surfaces of each successive exuviae bear the imprint of the hingement of the previous valve (Fig. 9(6,7)). The internal hingement and external imprint form the 'double-sided' hingement in each attached exuviae.

It seems likely that the external imprint of the hingement developed during a very short time just after the formation of the newly moulted flexible cuticle. The 'false' external hingement was formed along the dorsal margin of the new valve, due to strong pressure of the new cuticle against the old one (suggested moulting Stage A1). The hingement of the previous exuviae functioned as a mould for the "external hingement' of the new cuticle. These two structures formed together an interdigitated structure ('doublesided' hingement), which strengthened the connection of the successive attached exuviae (Fig. 11).

These observations suggest that the valves in Cryptophyllus species were joined by an uncalcified ligament located above the hingement and that the hingement was a vestigial structure. It had lost its original function as a pivot through evolution but developed minor new tasks, i.e. strengthening the shell connection and keeping the new shell in the correct position.

During ontogeny, the hingements of successive exuviae of Cryptophyllus slightly shifted ventrally, thus the dorsal margins of the previous exuviae are visible as a series of parallel striae in internal view (Figs. 5, 10) and, in the terminology of Jaanusson (1957, Fig. 1), an epicline dorsum was formed (see also Rome \& Goreux, 1960; Jones, 1962; Schallreuter, 1977). In contrast, in Schaefericoncha the hingements of successive exuviae slightly shifted dorsally during ontogeny, thus the dorsal margins of previous exuviae are visible as a series of parallel striae in external view and, in the terminology of Jaanusson (1957, Fig. 1), a hypocline dorsum was formed (Schallreuter, 1987, Fig. 2A/1; Figs. 1(5), 2(5) herein).

The hingements of Eridoconcha and Cryptophyllus were briefly described by Levinson (1950, p. 68, Fig. 5) and Rome \& Goreux (1960, p. 189) as composed of a ridge and groove. The presence of a crenulated hingement was observed by Jones (1962, pl. 2/12) in Cryptophyllus platyogmus Jones, 1962, from the Lower Carboniferous of the Bonaparte Gulf Basin, Australia, and by Casier \& Devleeschouwer (1995, pl. 3/4) in Cryptophyllus sinsinensis Casier \& Devleeschouwer, 1995, from the early Famennian of the Dinant Basin, Belgium.

Tubular structures One of the most interesting features of unknown biological affinity developed on the internal surface of each attached exuviae in $C$. socialis is the presence of fine cylindrical tubules (Figs. 12, 13, 14, 15, 16). These structures vary in shape, size and density in different parts of the shell and on different instars. The tubules are hollow, 
Fig. 11 Schematic diagram of possible development of the 'double-sided' hingement. The new hinge structure and external imprint of the previous valve hingement, developed during a very short time, just after ecdysis (a)

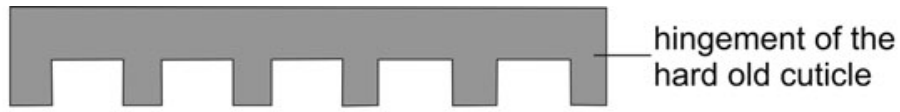

(b)

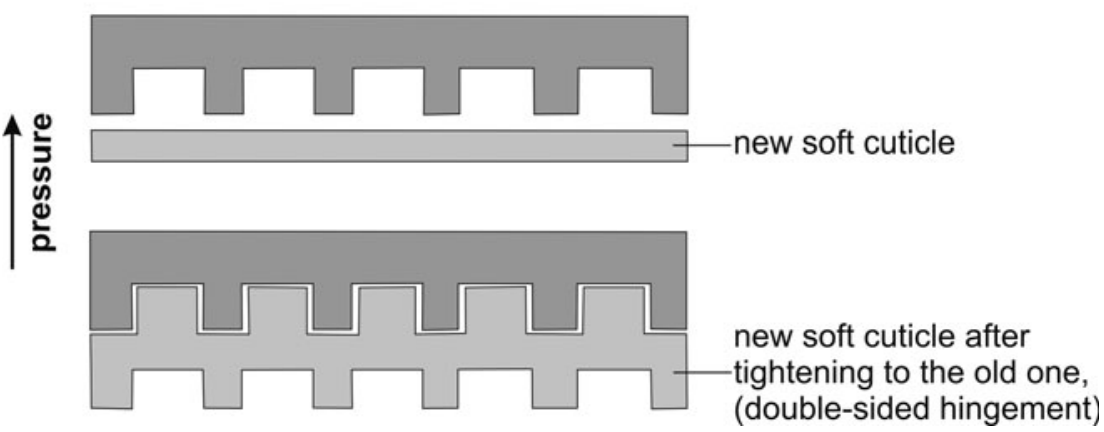

attached to the inner surface of the calcified outer lamella in small circular depressions, and open distally. In most cases, the tubules have been destroyed during the exfoliation process and only the two side walls are preserved.

Three distinct types of tubular structures can be distinguished in C. socialis. The first type (marginal tubules) is restricted to the free margin area of each valve. The tubules are distributed in one row in an almost concentric pattern, parallel to the free margin of each exuviae (Figs. 12, 13). They are uniform in width at the same stage and increase very slightly in diameter in the successive stages. In the adult stage, the marginal tubules are ca. $1 \mu \mathrm{m}$ in diameter and ca. $40-47 \mu \mathrm{m}$ long. The density of tubules is slightly smaller in the centro-ventral area. Through ontogeny the number of marginal tubules increases to reach approximately 100 in the adult stage (Fig. 12a).

The tubules are strongly curved in their proximal parts. In their central and distal parts, they run down vertically towards the ventral margin. Close to each tubule of the first and second type, there is a straight narrow groove extending from the interior of the basal depression and directed towards the median part of the valve (Fig. 13(1a, c)). The length of the grooves is approximately the same as the length of the accompanying tubule.

The second type (lateral tubules) is similar to the marginal tubules, although in this case the tubules are slightly shorter, reaching up to $25 \mu \mathrm{m}$ in length. They are also concentrically arranged in one to three parallel rows and occur more centrally than the row
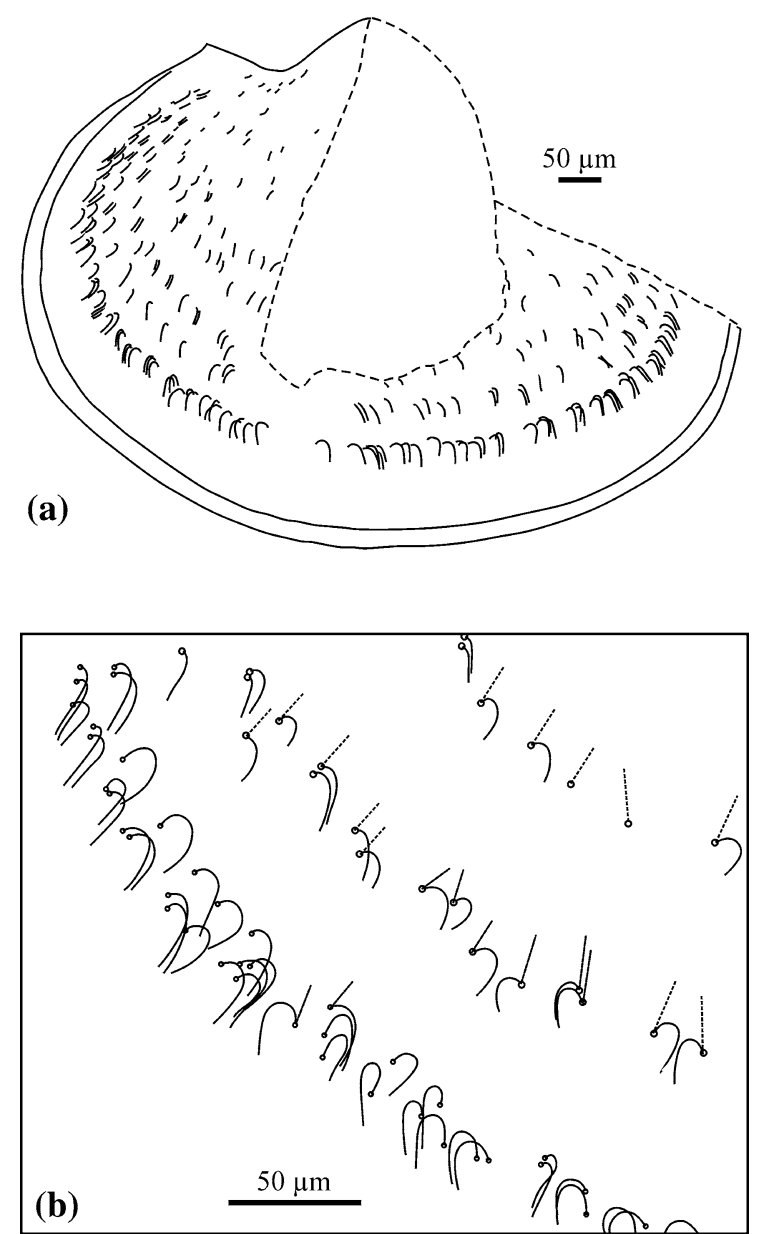

Fig. 12 Cryptophyllus socialis (Eichwald, 1860). a Schematic drawing showing pattern of tubular structures in adult specimen (ZPAL O.59/202), b close-up of marginal and lateral tubules in antero-ventral area (ZPAL O.59/210) 


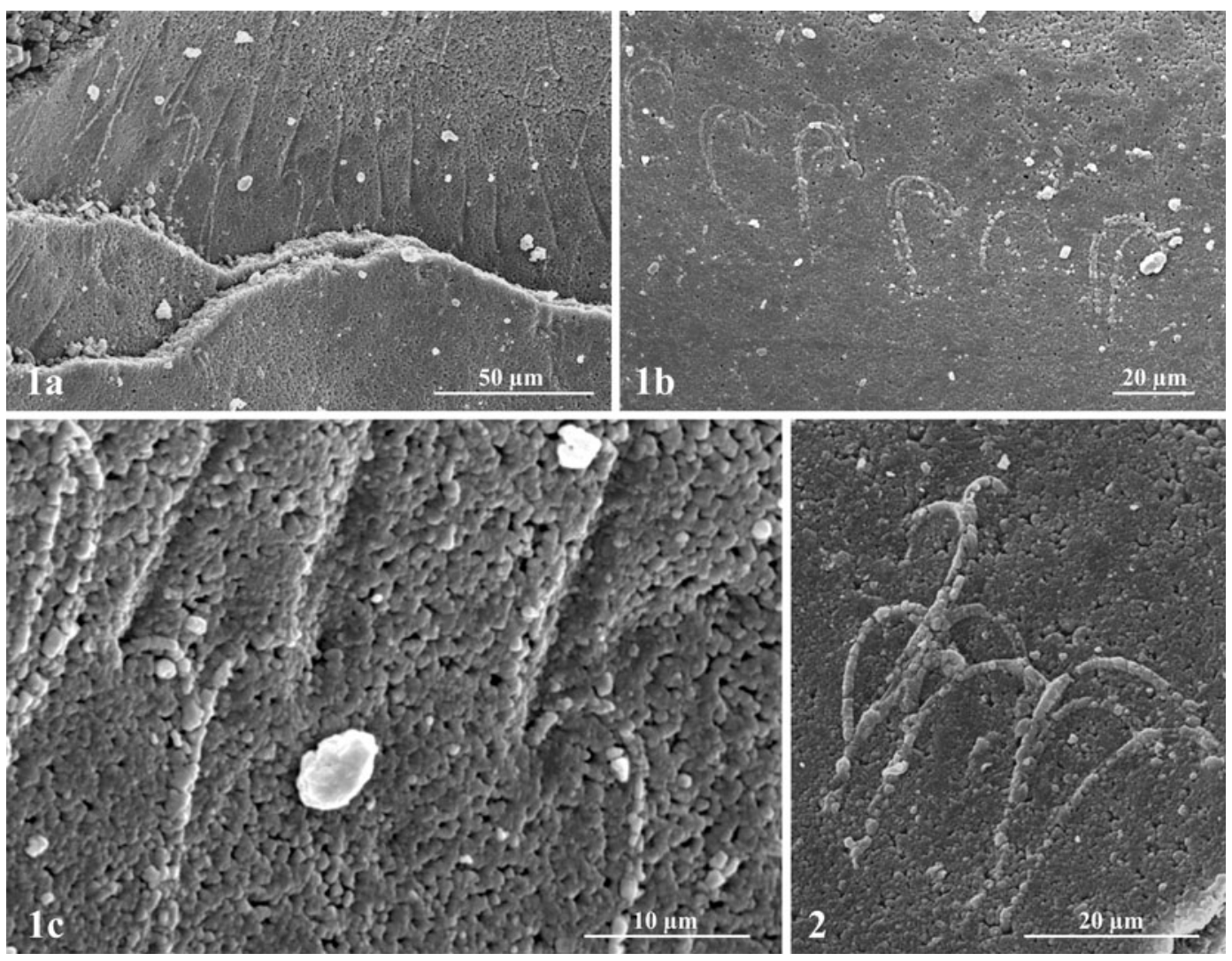

Fig. 13 Marginal tubules of Cryptophyllus socialis (Eichwald, 1860), Late Devonian (Early Famennian, Zadonsk Horizon), Kamenka section, Voronezh region, Russia. 1 strongly curved

of marginal tubules (Fig. 12a, b). The number of rows depends on the growth stage; in adult specimens, there are three concentric rows of lateral tubules. The lateral tubules are also strongly curved in a similar pattern as the marginal tubules.

Tubules of the third type (median tubules) are restricted to the median area of the shell and are distributed irregularly (Figs. 14, 15). They are shorter than the other two types, being 10-16 $\mu \mathrm{m}$ long and up to $1.5 \mu \mathrm{m}$ wide. The internal diameter of the interior of the median tubules varies from 400 to $540 \mathrm{~nm}$. The proximal ends of the tubules are attached to the calcified layer in small depressions. The median tubules are almost straight or slightly curved and run almost vertically towards the ventrum. There are no straight grooves close to the median tubules, which suggest that they lie almost as in their life position.

The medial tubules are widest at their distal ends. A fan-shaped structure composed of extremely thin marginal tubules and narrow grooves indicating their previous position (ZPAL O.59/210), 2 close-up of marginal tubules (ZPAL O.59/266)

and long, densely spaced, branching striae is developed at the distal ends of all the tubules. The fanshaped structures seem to extend from the open interior of the tubules (Figs. 14, 15). The median tubules are developed close to the internal ridge area and were not observed in other parts of the shell.

Tubules of all types occur often in groups of two or three. All instars possess a common tubuledistribution pattern, and the number of tubules increases through ontogeny.

The external surface of each exuviae bears imprints of tubular structures, developed as curved grooves, and small tubercles that represent imprints of cavity depressions (Fig. 16). The external imprints of tubular structures have been observed on the external surface of very early stages.

The interpretation of the tubular structures is problematic. The structure and pattern of the tubular structures is different from that seen in any other known crustacean. SEM observations have not shown 


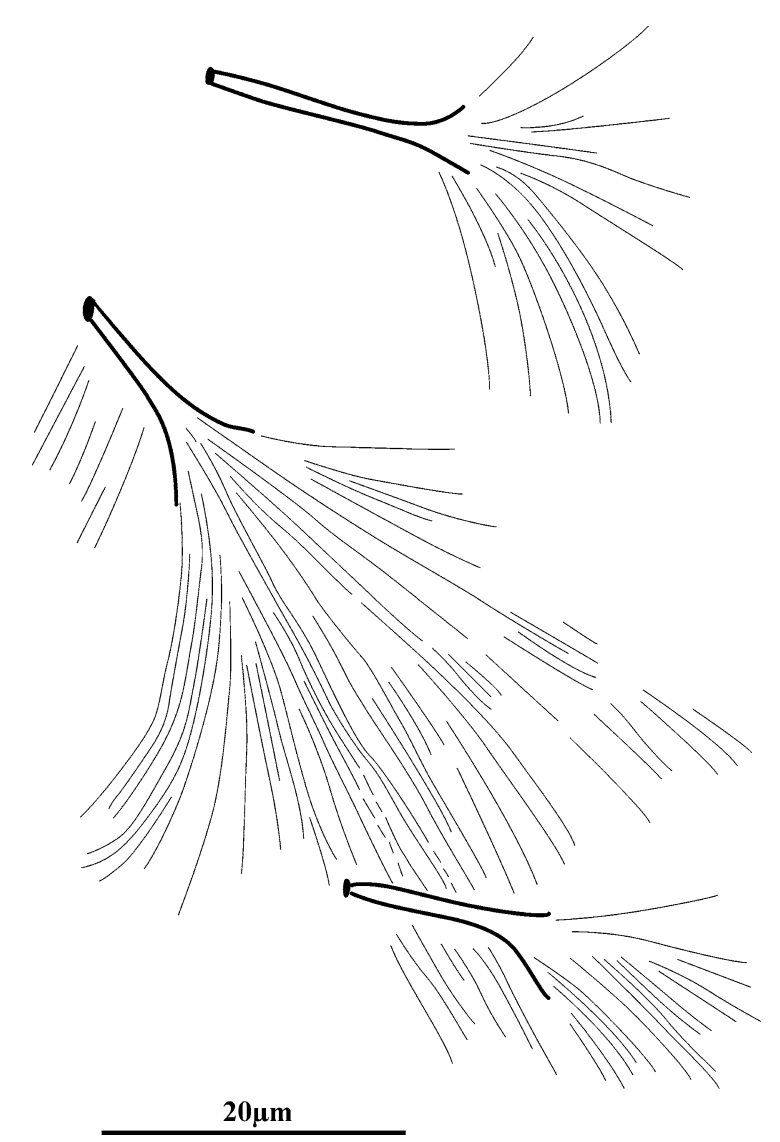

Fig. 14 Schematic drawing of median tubules, and fan-like structures of Cryptophyllus socialis (Eichwald, 1860), (ZPAL O.59/223)

the existence of pore exits on the external surface of the successive exuviae, especially along the growth lines, suggesting that the vertical pore-canals pass through the calcified outer lamellae.

The morphological evidence presented above indicates that the straight grooves were the places of the previous position of the tubules. Probably the soft and flexible marginal and lateral tubules were removed from their previous position, rotated and strongly curved, while those at the median part were not subject to distortion. It seems that the tubules were curved during moulting in a very short time, as a result of water pressure connected with rapid cuticle changes from a wrinkled sheet.

The marginal and lateral tubules were curved clockwise in the anterior part (with some exceptions) and counter-clockwise in the posterior part of the valve. Therefore, just after ecdysis the pressure of water absorption must have taken place from the dorsal direction (body?) along both sites of the adductorial muscles (? internal ridge).

In ostracods, the pore canals pass vertically through the cuticle and terminate on the top of the epicuticle (e.g. Hartmann, 1968; Sandberg \& Plusquellec, 1969; Okada, 1982a, 1983a; Keyser, 1982, 1983, 1995). In the living animal, the pore system consists of simple or branching narrow organic tube through which the external sensilla are connected to nerve cells in the epidermal layer. Other vertical canals that penetrated the cuticle of Recent ostracods are secretory pore canals. The marginal pore canals are much dense, longer and narrower than the normal pores.

The dimensions of tubules in $C$. socialis are comparable to those of pore canals in Recent ostracods. Because of the lack of pore exits on the external surface of $C$. socialis and the flexible nature of the tubules during rotation, coupled with their close similarity to the simple pore canals in Recent ostracods, the hypothesis is herein proposed that these structures represent vestigial structures (pore canals), which lost most of their original function (as tactile receptors in ostracods) through evolution. Their original function probably disappeared early in ontogeny, and a minor new function developed. A possible secretory function of the tubules is suggested. The formation and penetration of the cuticle by pore canals was probably stopped during moulting due to the covering of the external surface by the retained valves. The tubular structures thus were no longer in use as pore canals but they indicate the common ancestry with other ostracod taxa (leperditellids and/or beyrichioideans).

The function of the fan-shaped structures is more problematic. If the tubular structures represent vestigial pore canals, the fan-structures are possibly the marks of nerve-fibres which passed through the tubules in bundles. It is also not too unlikely that the fan-shaped structures may be diagenetic artefacts.

The imprints of tubules were probably produced similarly to the external 'false' hingement on the external shell surface of the non-calcified, soft layer of the cuticle of the newly moulted individual. They were formed, when the new cuticle was fully grown, due to the pressure of the new valve against the inner surface of the previous valve, where the tubules were strongly sclerotized. Similar tubular structures have been reported by Langer (1973, pl. 10/6) in one specimen of Eridoconcha sp. A from the Middle Devonian of Germany. 

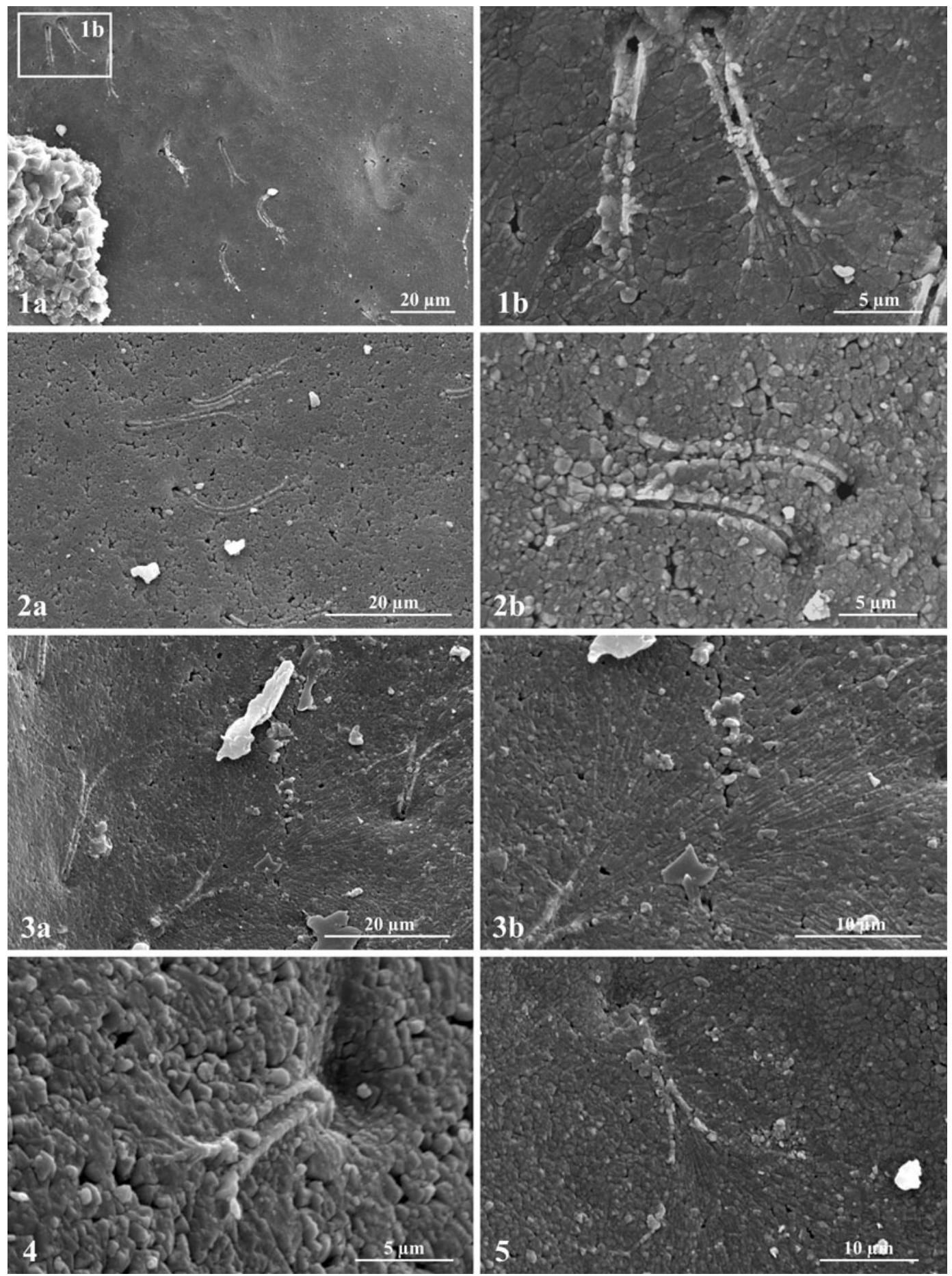

Fig. 15 Median tubules and fan-like structures of Cryptophyllus socialis (Eichwald, 1860), note that only side walls are preserved. 1a LV, median tubules developed between AMS and Fr.; 1b close-up of 1a showing median tubules and fan-like structures (ZPAL O.59/257), 2a median tubules, ventral to the

right, 2b median tubules, ventral to the left (ZPAL O.59/211), 3 median tubules and fan-like structures, dors. and close-up of fan-like structure (ZPAL O.59/223), 4 median tubule (ZPAL O.59/262), 5 median tubule and fan-like structure (ZPAL O.59/ 295) 

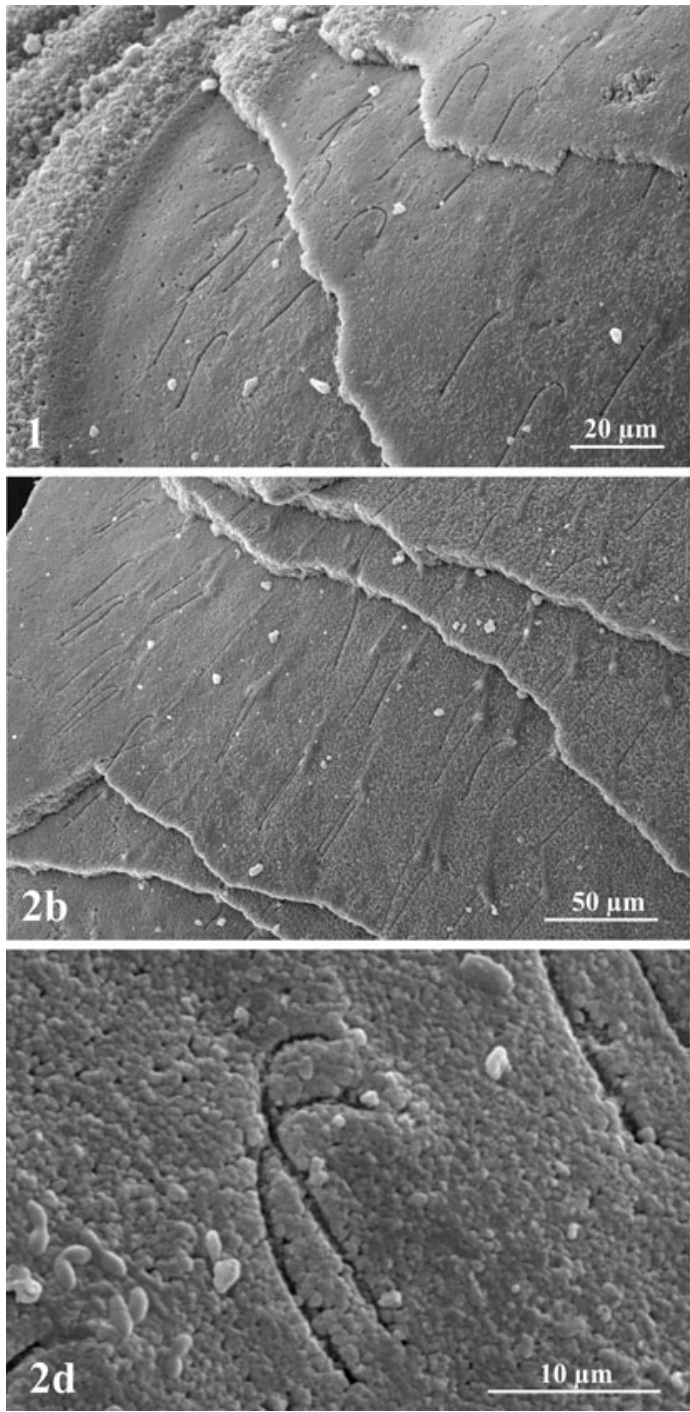

Fig. 16 External imprints of marginal and lateral tubules of Cryptophyllus socialis (Eichwald, 1860). 1 imprints visible on three partly exfoliated exuviae (ZPAL O.59/263), 2ac imprints of lateral tubules and straight grooves on successive

The tubular structures were also considered to represent 'cell-to-cell connections', which occur in Recent ostracods and connect the outer and inner epidermal cells (see Okada, 1982a; Keyser, 1995, 2005). According to Keyser (2005), these structures stabilize the outer and inner epidermal layer and minimize the free space between both layers. However, the presence of empty space inside the tubules, their arrangement in rows, the presence of the fan-like structures, as well as their occurrence inside the body attachment area (isthmus), where the
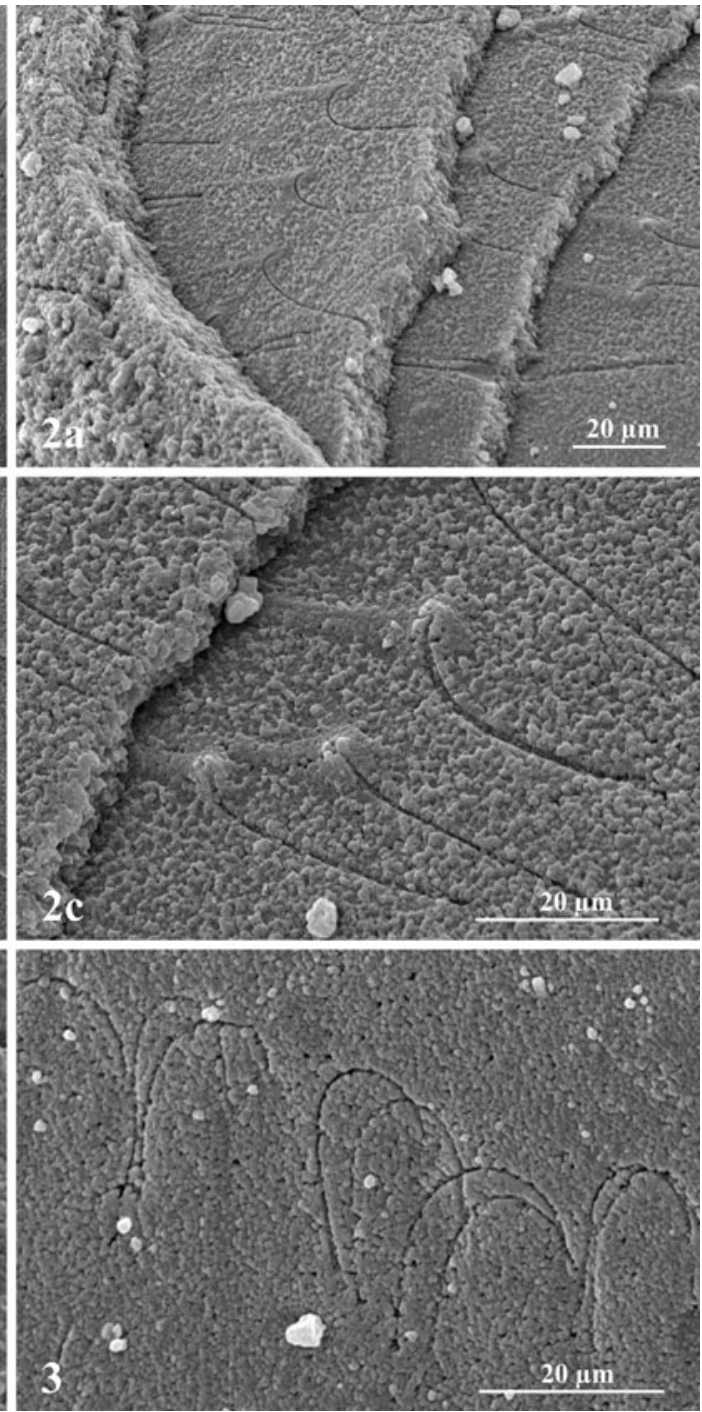

exfoliated exuviae, a \& $\mathbf{c}$ ventral to the right; $\mathbf{d}$ imprints of marginal tubules (ZPAL O.59/225), 3 imprints of marginal tubules (ZPAL O.59/202)

connection between the inner and outer epidermal cell layers is lost in Recent ostracods, testify against this interpretation.

\section{Discussion}

\section{Palaeoecology}

The rich monospecific assemblage of $C$. socialis associated with the ostracod Serenida sp., rare 
Acratia sp. and low diversity but abundant brachiopod (rhynchonellid) faunas occurs in shallow marine carbonate facies in the lower part of the lower Famennian (Zadonsk Horizon) strata (Sokiran, 2002, 2003). C. socialis probably inhabited shallow and possibly lagoonal waters.

Casier \& Devleeschouwer (1995) noted the presence of abundant specimens of Cryptophyllus sinsinensis in a rich, but poorly diversified supposed shallow marine assemblage in the lower part of the Famennian in Sinsin (Dinant Basin, Belgium). Copland (1982) suggested that the Middle Ordovician Cryptophyllus fauna of North America inhabited a deep platform environment. Jones (1989) and Bless (1983) suggested a marine nearshore realm for Cryptophyllus in the Late Devonian and Early Carboniferous of Western Australia and the Late Devonian of Western Europe.

Spinicaudatans inhabit temporary freshwater bodies and most representatives of this group do not tolerate low salinities (see Tasch, 1969; Thiéry, 1996).

\section{Affinities of the Eridostracina}

The affinities of cryptophyllids and eridoconchids remain controversial. Unfortunately, there is no record of an eridostracine species with the soft parts preserved. Both groups share many characters with various Palaeozoic Ostracoda, such as the muscle scars pattern, the presence of an adductorial sulcus, and the separation of the attached valves at the dorsal margin. The resemblance between the multilayered carapace of ostracods and spinicaudatans may be a case of homeomorphy.

Morphological evidence such as the lack of a calcified inner lamella in $C$. socialis, a random aggregate adductor muscle scar, a straight dorsal margin and the presence of vestigial structures (pore canals and hingement) suggest that their ancestors may lie within the palaeocopid ostracods. However, in contrast, in some mid- and late-Palaeozoic palaeocopids, a poorly developed calcified inner lamella developed (Olempska, 1999, 2008).

Moult retention in ostracods first appeared in the most primitive early Ordovician ostracods (Conchoprimitia). The oldest species of Conchoprimitia (C. sp. of Tinn \& Meidla, 2004) with a retention of two exuviae is from the Arenig (Volhov) of Baltoscandia (Tinn \& Meidla, 2004). The cryptophyllids and eridoconchids started their adaptive radiation in the Middle Ordovician. Their ancestry has not been explored satisfactorily, mostly due to the poor state of preservation of the early Ordovician ostracods. Little is known about their internal structures.

The external morphology (deep median sulcus, two dorsal swellings on each side of a dorsal sulcus) of partly exfoliated specimens of Americoncha [A. multiannulata (Levinson, 1951)] from the Middle Ordovician is very similar to that in the leperditellid Milleratia Swartz, 1936. The external morphology of Americoncha dubia Warshauer \& Berdan, 1982, is similar to that in the leperditellid Laccoprimitia Ulrich \& Bassler, 1923 species.

The external morphology of Pygoconcha species (P. trilamellae Schallreuter, 1968; P. baltica Schallreuter, 1987) from erratic boulders of Middle Ordovician age is very similar to that in species of the leperditellid Parapyxion Jaanusson, 1957 from the Middle and Upper Ordovician of Sweden and Bohemia (Schallreuter, 1987).

Schaefericoncha (S. theatri Schallreuter, 1987) first appeared in the fossil record in the mid-Silurian (Wenlock series) (Schallreuter 1987, 1995). The first larval valve is not preserved in $S$. theatri; the wide, deep and long adductorial sulcus, large anterodorsal node and long hinge margin, visible on the lateral surface in exfoliated specimens (Schallreuter, 1995, pl. 10A/3), however, are similar to that in many beyrichioidean ostracods.

The ornamentation of the first valve preserved in $S$. dorsospina from the Upper Devonian of Poland and Germany is very similar to that in some beyrichioidean species, such as the early growth stage of Kozlowskiella kozlowskii (Přibyl, 1953) from the Middle Devonian of the Holy Cross Mountains, Poland (Fig. 1(9)).

Jaanusson (1957) included the genera Eridoconcha, Cryptophyllus, Conchoprimitia, Schmidtella, Milleratia, Primitia and Parapyxion in the family Leperditellidae and proposed a new superfamily Leperditellacea Ulrich \& Bassler, 1906. According to Jaanusson (1957), the Leperditellidae are 'one of the earliest palaeocope families appearing already in the Lower Arenigian'.

The suggestion of Schallreuter (1977) of a possible close relationship between Cryptophyllus gutta and the Podocopida does not seem likely, at least based on the light microscopic analysis of $C$. socialis and C. plicatus, showing the absence of a calcified inner 
lamella. The presence of a 'broad duplicature' in $C$. gutta seems to be an artefact, produced by the breakdown of an extremely thin median part of the shell.

The equivalved carapaces, lack of valve overlap and lack of a calcified inner lamella in eridostracines, may represent relict primitive characters of ancient ostracods and could be an important character for evaluating the history of ostracods since the Palaeozoic. The leperditellid and/or conchoprimitid ancestors most probably gave rise to diverse cryptophyllid and eridoconchid lineages.

These points suggest that the eridostracines may be a polyphyletic group, containing aberrant representatives of different families/superfamilies such as the conchoprimitids, leperditellids and beyrichioideans, but further research is required to confirm this suggestion. This conclusion should perhaps now be tested using cladistics but such analysis lies outside the scope of the present study.

\section{Conclusions}

1 Features linking Eridostracina to Ostracoda include: adductor muscle scars similar to that in some palaeocopids and podocopid healdioideans; the presence of frontal and dorsal scars; the presence of a sulcus, expressed internally by a corresponding ridge, similar to that in palaeocopid ostracods; the presence of a vestigial hinge structure; and the separation of valves at the dorsal margin.

2 The presence of vestigial pore canals in eridostracines suggests that they must have descended from ancestors that had pore canals.

3 The function of the vestigial pore canals remains unknown.

4 The vestigial hingement lost its original function as a pivot but developed a new task as a structure strengthening the connection of the retained valves.

5 Eridostracines commonly occur in marginalmarine environments, with unstable physicalchemical conditions (salinity, temperature, nutrient supply). The influence of external factors on the disruption of hormonal pathways in some ostracods probably influenced the moulting process (moulting retention) and genetically modified populations of aberrant ostracods that could tolerate this environment could have occurred (e.g. Eridoconcha and Cryptophyllus lineages).

6 It is suggested that eridostracines are a polyphyletic group, probably comprising ancestors among the conchoprimitids, leperditellids and beyrichioidean ostracods.

7 The presence of cuticle retention in Eridostracina and Spinicaudata is likely to be homeomorphic.

Acknowledgments I thank Dr. Elena Sokiran (VSEGEI Institute, St. Petersburg) for placing the material of Cryptophyllus socialis in my disposal. I also thank David J. Siveter (University of Leicester, Leicester) and anonymous reviewer for their helpful reviews. I am grateful to B. Waksmundzki (University of Warsaw) for preparation of some drawings.

Open Access This article is distributed under the terms of the Creative Commons Attribution Noncommercial License which permits any noncommercial use, distribution, and reproduction in any medium, provided the original author(s) and source are credited.

\section{References}

Abushik, A. F., 1990. Order Eridocopida Adamczak, 1961. In Abushik, A. F. (ed.), Practical Manual on Microfauna of USSR. Volume 4. Palaeozoic Ostracoda. Ministry of Geology of USSR, All-Union Geological Research Institute, NEDRA, Leningrad: 53-54.

Adamczak, F., 1958. The ontogeny and evolution of Kozlowskiella (Přibyl) (Ostracoda). Acta Palaeontologica Polonica 3: 75-118.

Adamczak, F., 1961. Eridostraca - a new suborder of ostracods and its phylogenetic significance. Acta Palaeontologica Polonica 6: 29-104.

Adamczak, F., 1976. Middle Devonian Podocopa (Ostracoda) from Poland; their morphology, systematics and occurrence. Senckenbergiana Lethaea 57: 256-467.

Andersson, A., 1974. Musculature and muscle scars in the cytherid ostracode Cytheridea papillosa (Bosquet). Zoologica Scripta 3: 83-90.

Anger, K., 2006. Contributions of larval biology to crustacean research: a review. Invertebrate Reproduction Development 49: 175-205.

Bassler, R. S. \& B. Kellett, 1934. Bibliographic index of Paleozoic Ostracoda. Geological Society of America, Special Papers 1: 1-500

Bate, R. H. \& B. A. East, 1972. The structure of the ostracode carapace. Lethaia 5: 177-194.

Bate, R. H. \& L. M. Sheppard, 1982. The shell structure of Halocypris inflata (Dana, 1849). In Bate, R. H., E. Robinson \& L. M. Sheppard (eds), Fossil and Recent Ostracods. British Micropalaeontological Series. Ellis Horwood Limited, Chichester: 25-50. 
Becker, G., 1964. Palaeocopida (Ostracoda) aus dem Mitteldevon der Sötenicher Mulde (N-Eifel). Senckenbergiana Lethaea 45: 43-113.

Becker, G., 1996. The development of the adductor muscle scar field in Palaeozoic ostracods. In Keen, M. C. (ed.), Proceedings of the 2nd European Ostracodologists Meeting. British Micropalaeontological Society: 5-8.

Becker, G., 2005. Functional morphology of Palaeozoic ostracods: phylogenetic implications. In Ikeya, N., A. Tsukagoshi \& D. J. Horne (eds), Evolution and Diversity of Ostracoda. Hydrobiologia 538: 23-53.

Becker, G. \& M. J. M. Bless, 1974. Ostracode stratigraphy of the Ardenno-Rhenish Devonian and Dinantian. In International Symposium on Namur 1974, Belgian Micropaleontological Limits from Emsian to Viséan, Ministry of Economic Affairs, Brussels, Belgium: 1-52.

Becker, G. \& W. K. Braun, 2007. Extra-lobal and complex dimorphic features in Middle Devonian palaeocopine ostracods. Hydrobiologia 585: 141-157.

Becker, G. \& L. C. Sanchez de Posada, 1977. Ostracoda aus der Moniello-Formation Asturiens (Devon: N-Spanien). Palaeontographica A 158: 115-203.

Becker, G., N. Lazreq \& K. Weddige, 2004. Ostracods of Thuringian provenance from the Devonian of Morocco (Lower Emsian-middle Givetian; south-western AntiAtlas). Palaeontographica A 271: 1-109.

Bless, M. J. M., 1983. Late Devonian and Carboniferous ostracode assemblages and their relationship to the depositional environment. Bulletin de la Société belge de Géologie 92: 31-53.

Bless, M. J. M. \& D. Massa, 1982. Carboniferous ostracodes in the Rhadamès Basin of western Libya: paleoecological implications and comparison with North America, Europe and the USSR. Revue de l'Institut Francais du Petrole 1: 19-61.

Blumenstengel, H., 1997. Ostracodenfaunen des Frasniums der Inseln Rügen und Hiddensee (Mecklenburg-Vorpommern). Freigerger Forschungsheft C 466: 61-83.

Casier, J.-G. \& X. Devleeschouwer, 1995. Arguments (Ostracodes) pour une régression culminant à proximité de la limite Frasnien-Famennien, à Sinsin (Bord sud du Bassin de Dinant, Belgique). Bulletin de l'Institut royal des Sciences naturelles de Belgique, Sciences de la Terre 65: $51-68$.

Clarke, J. M., 1882. New phyllopod crustaceans from the Devonian of western New York. American Journal of Sciences, 3rd series, 23: 476-477.

Cooper, C. I., 1945. Moult stages of the Pennsylvanian ostracode Ectodemites plummeri. Journal of Paleontology 19: 368-375.

Cooper, C. L., 1946. Pennsylvanian ostracodes of Illinois. Bulletin of the Illinois State Geological Survey 70: 1-177.

Copeland, M. J., 1977. Early Paleozoic Ostracoda from southwestern District of Mackenzie and Yukon Territory. Bulletin of the Geological Survey of Canada 275: 1-88.

Copland, M. J., 1982. Bathymetry of early Middle Ordovician (Chazy) ostracodes, lower Esbataottine formation, District of Mackenzie. Bulletin of the Geological Survey of Canada 347: 1-39.

Dahmer, G., 1927. Der Kahlebergsandstein im profil am Mittleren Schalker Teich im Oberharz. Jahrbuch der
Preussischen Geologischen Landesanstalt zu Berlin 48: 215-224.

Díaz Saravia, P. \& P. J. Jones, 1999. New Carboniferous (Namurian) glaciomarine ostracods from Patagonia, Argentina. Journal of Micropalaeontology 18: 97-109.

Drach, P., 1939. Mue et cycle d'intermue chez les Crustaces Decapodes. Annales de l'Institut Oceanographique 19: 103-391.

Egorov, V. G., 1954. Sistematičeskoe položenie gruppy Astarte socialis iz devonskich otloženij Russkoj platformy. Trudy VNIGNI Paleontologičeskij Sbornik 1: 22-30.

Eichwald, E., 1860. Lethaea Rossica on Paléontologie de la Russie, Schweizerbart'sche Verlagsbuchhandlung, Stutgart: $1654 \mathrm{pp}$.

Gorak, S. V., 1966. Ostracoda. In The Fauna of the Lowermost Tournaisian (Zone C1 T A) in the Donetz Basin. Naukova Dumka, Kiev: 90-115 (in Russian).

Gramm, M. N., 1982. The systematic position of the ostracod genus Healdianella Posner, 1951. In Bate, R. H., E. Robinson \& L. M. Sheppard (eds), Fossil and Recent ostracods. British Micropalaeontological Series. Ellis Horwood Limited, Chichester: 193-218.

Gross, W., 1934. Eine Estheria aus dem rheinischen Unterdevon. Senckenbergiana 16: 309-313.

Hadding, A., 1913. Undre Dicellograptusskiffern I Skåne jämpte några därmed ekvivalenta bildningar. Kungliga Fysiografiska Sällskapets Handlingar 24: 1-90. Lund.

Harris, R. W., 1931. Descriptions and illustrations of ostracodes. In Decker, Ch. E. \& C. A. Merritt (eds), The Stratigraphy and Physical Characteristics of the Simpson Group. Bulletin of Oklahoma Geological Survey 55: 87-94.

Harris, R. W., 1957. Ostracoda of the Simpson Group. Oklahoma Geological Survey 75: 1-333.

Hartmann, G., 1963. Zur phylogenie und systematik der Ostrakoden. Zeitschrift für Zoologische Systematik und Evolutionsforschung 1: 1-154.

Hartmann, G., 1968. Ostracoda (2. Lieferung). In Gruner, H.-E. (ed.), Dr. H.G. Bronns Klassen und Ordnungen des Tierreichs. Band 5 (Arthropoda), Abteilung I (Crustacea), Buch 2, Teil IV (Ostracoda) Akademische Verlagsgesellschaft, Leipzig: 217-408.

Hartnoll, R. G., 2001. Growth in Crustacea - twenty years on. In Paula, J. P. M., A. A. V. Flores \& C. H. J. M. Fransen (eds), Advances in Decapod Crustacean Research. Hydrobiologia 449: 111-122.

Henningsmoen, G., 1953. Classification of Paleozoic straighthinged ostracods. Norsk Geologisk Tidsskrift 31: 185-288.

Hoare, R. D. \& G. K. Merrill, 2004. A Pennsylvanian (Morrowan) ostracode fauna from Texas. Journal of Paleontology 78: 185-204.

Horne, D. J., A. Cohen \& K. Martens, 2002. Taxonomy, morphology and biology of quaternary and living Ostracoda. Geophysical Monograph 131: 5-36.

Ishizaki, K., 1968. Ostracodes from Uranouchi Bay, Kochi prefecture, Japan. Science Reports of the Tohoku University, Series 2 (Geology) 40: 1-45.

Jaanusson, V., 1957. Middle Ordovician ostracodes of central and southern Sweden. Bulletin of the Geological Institutions of the University of Uppsala 37: 173-442. 
Jones, P. J., 1962. The ostracod genus Cryptophyllus in the Upper Devonian and Carboniferous of Western Australia. Bureau of Mineral Resources, Geology and Geophysics, Bulletin 62: 1-37.

Jones, P. J., 1968. Upper Devonian Ostracoda and Eridostraca from the Bonaparte Gulf Basin, northwestern Australia. Bureau of Mineral Resources, Geology and Geophysics, Bulletin 99: 1-109.

Jones, P. J., 1989. Lower Carboniferous Ostracoda (Beyrichicopida and Kirkbyocopida) from the Bonaparte Basin, northwestern Australia. Bureau of Mineral Resources, Geology and Geophysics, Bulletin 228: 1-97.

Jones, P. J., 2003. Ankumia van Veen, 1932 (nomen dubium): pathological moult retention in the Cytherellidae (Platycopida: Ostracoda). Journal of Micropalaeontology 22: 85-99.

Jones, T. R., 1850. Description of the Entomostraca of the Pleistocene beds of Newbury, Copford, Clacton and Grays. Annals and Magazine of Natural History, Series II 6: 25-28.

Jørgensen, N. O., 1970. Ultrastructure of some ostracods. Bulletin of the Geological Society of Denmark 20: 79-92.

Keenan, J. E., 1951. Ostracodes from the Maquoketa shale of Missouri. Journal of Paleontology 25: 561-574.

Kesling, R. V., 1951. The morphology of ostracod molt stages. Illinois Biological Monographs 21: 1-324.

Keyser, D., 1982. Development of sieve pores in Hirschmannia viridis (O. F. Müller, 1785). In Bate, R. H., E. Robinson \& L. M. Sheppard (eds), Fossil and Recent Ostracods. British Micropalaeontological Series. Ellis Horwood Limited, Chichester: 51-60.

Keyser, D., 1983. Ultrastructure of carapace-sensilla in Aurila convexa (Baird, 1850) (Ostracoda, Crustacea). In Maddocks, R. F. (ed.), Applications of Ostracoda. Proceedings of the Eight International Symposium on Ostracoda. Department of Geoscience, University of Houston, Houston, TX: 649-658.

Keyser, D., 1990. Morphological changes and function of the inner lamella layer of podocopid Ostracoda. In Whatley, R. \& C. Maybury (eds), Ostracoda and Global Events. British Micropalaeontological Society Publication Series. Chapman and Hall, London, NY: 401-410.

Keyser, D., 1995. Structural elements on the surface of ostracod shells. In Riha, J. (ed.), Ostracoda and Biostratigraphy. Balkema, Rotterdam: 5-10.

Keyser, D., 2005. Histological peculiarities of the noding process in Cyprideis torosa (Jones) (Crustacea, Ostracoda). Hydrobiologia 538: 95-106.

Keyser, D. \& R. Walter, 2004. Calcification in ostracodes. Revista Española de Micropaleontología 36: 1-11.

Kobayashi, T., 1972. On the two discontinuities in the history of the order Conchostraca. Proceedings of the Japan Academy 48: 725-729.

Kolmodin, L., 1869. Bidrag till Kännedomen om Sveriges siluriska ostracoder. Akademisk Afhandling, Filosofiska Fakulteten, Upsala: 1-23.

Krandijevsky, V. S., 1958. On the first occurrence of the ostracod genus Eridoconcha in Silurian deposits of the USSR. Geologicheskiy Zhurnal Akademii Nauk Ukrainskoy SSR 18: 44-55. (in Ukrainian).
Kuballa, A. V., D. J. Merritt \& A. Elizur, 2007. Gene expression profiling of cuticular proteins across the moult cycle of the crab Portunus pelagicus. BMC Biology 5: $1-26$.

Langer, W., 1973. Zur Ultrastruktur, Mikromorphologie und Taphonomie des Ostracoda-Carapax. Palaeontographica A144: 1-54.

Le Fevre, J., 1963. Microfaunes de l'Emsien et du Dévonien moyen de la region Ougarta-Saoura (Sahara). S.N.P.A. Direction Exploration \& Production, Centre de Recherches Pau. Diplome d'Études Supérieures, Universite de Bordeaux, Pau: 1-180.

LeBlanc, G. A., 2007. Crustacean endocrine toxicology: a review. Ecotoxicology 16: 61-81.

Levinson, S. A., 1950. The hingement of Paleozoic Ostracoda and its bearing on orientation. Journal of Paleontology 24: 63-75.

Levinson, S. A., 1951. Thin sections of Paleozoic Ostracoda and their bearing on taxonomy and morphology. Journal of Paleontology 25: 553-560.

Levinson, S. A., 1961. Family Leperditellidae Ulrich and Bassler, 1906. In Moore, R. C. (ed.), Treatise on Invertebrate Paleontology, Part Q. Arthropoda 3, Crustacea, Ostracoda. Geological Society of America and University of Kansas Press, Lawrence: Q188-Q193.

Martin, J. W., 1992. Branchiopoda. In Harrison, F. E. \& A. G. Humes (eds), Microscopic Anatomy of Invertebrates, Vol. 9. Wiley-Liss, New York: 25-224.

Martinsson, A., 1956. Ontogeny and development of dimorphism in some Silurian ostracodes. The Bulletin of the Geological Institutions of Uppsala 37: 1-42.

Martinsson, A., 1962. Ostracodes of the family Beyrichiidae from the Silurian of Gotland. The Bulletin of the Geological Institutions of Uppsala 41: 1-369.

Matern, H., 1929. Die Ostracoden des Oberdevons. I. Teil. Aparchitidae, Primitiidae, Zygobolbidae, Beyriichidae, Kloedenellidae, Entomidae. Abhandlungen der Preussischen Geologischen Landesanstalt, Neue Folge 118: 1-99.

Müller, G. W., 1894. Die Ostracoden des Golfes von Neapel und der angrenzenden Meeres-Abschnitte. Die Fauna und Flora des Golfes von Neapel. Monograph 21: 1-404.

Neckaja, A. I., 1966. Ostrakody ordovika i silura SSSR (semeystva Schmidtellidae, Rectellidae, Longisculidae i nekotorye novye vidy drugich semeystv). Trudy VNIGRI 251: 1-104.

Novozhilov, N. I. 1960. Suborder Conchostraca Sars, 1846. In Y. A. Orlov (ed.), Osnovy Paleontologii, Vol. 8. Akademii Nauk SSSR, Moskva: 220-253.

Okada, Y., 1982a. Ultrastructure and pattern of the carapace of Bicornucythere bisanensis (Ostracoda, Crustacea). In Hanai, T. (ed.), Studies on Japanese Ostracoda, Bulletin No. 20. University of Tokyo Press, Tokyo: 229-267.

Okada, Y., 1982b. Structure and cuticle formation of the reticulated carapace of the ostracode Bicornucythere bisanensis. Lethaia 15: 85-101.

Okada, Y., 1983a. Ultrastructure and functions of pores of ostracods. In Maddocks, R. F. (ed.), Applications of Ostracoda. Proceedings of the Eight International Symposium on Ostracoda, July 26-29, 1982. Department of Geoscience, University of Houston, Houston, TX: 640-648. 
Okada, Y., 1983b. Muscle scars and structure of the muscle attachment in the carapace of the ostracode Bicornucythere bisanensis. Micropaleontology 29: 66-77.

Okubo, I., 1975. Recent marine Ostracoda in the Inland Sea, Japan-1: Callistocythere pumila Hanai, 1957 and Leguminocythereis bisanensis sp. nov. in the Inland Sea, Japan Ostracoda). Proceedings of the Japanese Society of Systematic Zoology 11: 23-31.

Olempska, E., 1999. Silicified shallow-water ostracodes from the Early Carboniferous of South China. Acta Palaeontologica Polonica 44: 383-436.

Olempska, E., 2004. Late Triassic spinicaudatan crustaceans from southwestern Poland. Acta Palaeontologica Polonica 49: 429-442.

Olempska, E., 2008. Soft body-related features of the carapace and the lifestyle of Paleozoic beyrichioidean ostracodes. Journal of Paleontology 82: 717-736.

Olesen, J., 1998. A phylogenetic analysis of the Conchostraca and Cladocera (Crustacea, Branchiopoda, Diplostraca). Zoological Journal of Linnean Society 122: 491-536.

Olesen, J., 2000. An updated phylogeny of the Conchostraca Cladocera clade (Branchiopoda, Diplostraca). Crustaceana 73: 869-886.

Öpik, A., 1937. Ostracoda from the Ordovician Uhaku and Kukruse formations of Estonia. Publications of the Geological Institution of the University of Tartu 50: 1-74.

Orr, P. J. \& D. E. G. Briggs, 1999. Exceptionally preserved conchostracans and other crustaceans from the Upper Carboniferous of Ireland. Special Papers in Palaeontology 62: 1-68.

Orr, P. J., D. E. G. Briggs \& S. L. Kearns, 2008. Taphonomy of exceptionally preserved crustaceans from the Upper Carboniferous of southeastern Ireland. Palaios 23: 298-312.

Poltnig, W., 1983. Eridostraca aus dem Grazer Paläozoikum (Stmk., Österreich). Mitteilungen des Naturwissenschaftlichen Vereines für Steermark 113: 25-38.

Pribyl, A., 1953. The ostracodes of the Middle Devonian (Givetian) of Poland in the profile Grzegorzowice-Skały in the Góry Świętokrzyskie (St. Croix Mountains). Sbornik Ústředního Ústavu Geologického 20: 233-344.

Raymond, P. E., 1946. The genera of fossil Conchostraca - an order of bivalve Crustacea. Bulletin of the Museum of Comparative Zoology 96: 217-307.

Rieder, N., P. Abaffy, A. Hauf, M. Lindel \& H. Weishäupl, 1984. Funktionsmorphologische Untersuchungen an den Conchostracen Leptestheria dahalacensis und Limnadia lenticularis (Crustacea, Phyllopoda, Conchostraca). Zoologische Beiträge N. F. 28: 417-444.

Rome, D. R. \& J. Goreux, 1960. Cryptophyllus (Ostracodes) du Strunien de la Belgique. Mémoires de L'Institut Géologique de L'Universite de Louvain 21: 185-204.

Rosenfeld, A., 1982. The secretion process of the ostracod carapace. In Bate, R. H., E. Robinson \& L. M. Sheppard (eds), Fossil and Recent Ostracods. British Micropalaeontological Series. Ellis Horwood Limited, Chichester: $12-24$.

Rusconi, C., 1954. Las piezas “Tipos” del Museo de Mendoza. Revista del Museo de Historia Natural de Mendoza 7: 82-155.
Sandberg, P. A. \& P. L. Plusquellec, 1969. Structure and polymorphism of normal pores in cytheracean Ostracoda (Crustacea). Journal of Paleontology 43: 517-521.

Schallreuter, R., 1967. Neue Ostracoden aus ordovizischen Geschieben. Geologie 16: 615-631.

Schallreuter, R., 1968. Zur Taxonomie und Phylogenie der Eridostraca (Ostracoda). Paläontologische Zeitschrift 42: 105-119.

Schallreuter, R., 1977. On Cryptophyllus gutta Schallreuter. Stereo Atlas of Ostracod Shells 4: 1-8.

Schallreuter, R., 1978. Zur Phylogenie und Systematik der Ordovizischen Ostrakoden. Unpublished Habilitationsschrift, University of Hamburg, Hamburg: 1-173.

Schallreuter, R., 1981. Ordovizische Ostrakoden Argentiniens. Mitteilungen aus dem Geologisch-Paläontologischen Institut der Universität Hamburg 51: 9-21.

Schallreuter, R., 1987. Ostrakoden aus silurischen Geschieben Westfalens I. Geologie und Paläontologie in Westfalen 7: 43-55.

Schallreuter, R., 1993. Beiträge zur Geschiebekunde Westfallens II, Ostrakoden aus ordovizischen Geschieben II. Geologie und Paläontologie in Westfalen 27: 1-273.

Schallreuter, R., 1995. Beiträge zur Geschiebekunde Westfalens III, Ostrakoden aus silurischen Geschieben II. Geologie und Paläontologie in Westfalen 34: 5-145.

Schallreuter, R., 1999. Weitere mikrofossilien aus dem Ostrakodenkalk (Silur) der Lindener Mark bei Giessen (Hessen). Neues Jahrbuch für Geologie und Paläontologie Monatshefte 12: 713-724.

Schmidt, E. A., 1941. Ostrakoden aus den Bohdalec-Schichten und über die Taxonomie der Beyrichiacea. Abhandlungen der Senckenbergischen Naturforschenden Gesellschaft 454: $1-97$.

Schneider, J. A., 2001. Bivalve systematic during the 20th century. Journal of Paleontology 75: 1119-1127.

Schöne, B. R., E. Dunca, J. Fiebig \& M. Pfeiffer, 2005. Mutvei's solution: an ideal agent for resolving microgrowth structures of biogenic carbonates. Palaeogeography, Palaeoclimatology, Palaeoecology 228: 149-166.

Schram, F. R., 1986. Crustacea. Oxford University Press, New York: 606.

Sokiran, E. V., 2002. Frasnian-Famennian extinction and recovery of rhynchonellid brachiopods from the East European Platform. In Baliński, A., E. Olempska \& G. Racki (eds), Biotic responses to the Late Devonian global events. Acta Palaeontologica Polonica 47: 339-354.

Sokiran, E. V. 2003. Pozdnedevonskije spiriferidy (Brachiopoda) Vostočno Evropejskoj platformy - aspekty taksonomji i ekologii. Unpublished Doctoral Thesis, Uniwersytet Śląski, Sonowiec: 1-226.

Swartz, F. M., 1936. Revision of the Primitiidae and Beyrichiidae, with new Ostracoda from the Lower Devonian of Pennsylvania. Journal of Paleontology 10: 541-586.

Sylvester-Bradley, P. C. \& R. H. Benson, 1971. Terminology for surface features in ornate ostracodes. Lethaia 4 : 249-286.

Tasch, P., 1969. Branchiopoda. In Moore, R. C. (ed.), Treatise on Invertebrate Paleontology, Pt. R, Arthropoda 4, Vol. 1. Geological Society of America and University of Kansas Press, Lawrence: R128-R191. 
Thiéry, A., 1996. Branchiopodes. I. Orderes des anostracés, notostracés, Spinicadata et Laevicaudata (Anostraca Sars, 1867-Notostraca Sars, 1867-Spinicaudata Linder, 1945-Levicaudata Linder, 1945). In Forest, J. (ed.), Traité de Zoologie, anatomie, systématique, biologie, Tome VII, Crustacés, Fascicule 2, Généralités (suite) et systématique. Masson, Paris: 285-351.

Tinn, O. \& T. Meidla, 2004. Phylogenetic relationships of early-middle Ordovician ostracods of Baltoscandia. Palaeontology 47: 199-221.

Ulrich, E. O., 1890. New and little known American Paleozoic Ostracoda (1). Journal of the Cincinnati Society of Natural History 13: 104-137.

Ulrich, E. O. \& R. S. Bassler, 1906. New American Paleozoic Ostracoda: notes and descriptions of Upper Carboniferous genera and species. Proceedings of the United States National Museum, 30(1446): 149-164.

Ulrich, E. O. \& R. S. Bassler, 1923. Paleozoic Ostracoda: their morphology, classification and occurrence. Maryland Geological Survey, Reports Silurian 9: 271-391.

van Veen, J. E., 1932. Die Cytherellidae der Maastrchter Tuffkreide und des Kunrader Korallenkalkes von SüdLimburg. Verhandelingen van het Geologische- Mijnbouwkundig Genootschap voor Nederland en Kolonien, Geologische Serie 9: 317-364.

Vannier, J., A. Thiéry \& P. R. Racheboeuf, 2003. Spinicaudatans and ostracods (Crustacea) from the Montceau Lagerstätte (Late Carboniferous, France): morphology and palaeoenvironmental significance. Palaeontology 46: 999-1030.

Warshauer, S. M. \& J. M. Berdan, 1982. Palaeocopid and podocopid Ostracoda from the Lexington Limestone and
Clays Ferry Formation (Middle and Upper Ordovician) of Central Kentucky. Geological Survey Professional Paper 1066-H: H1-H80.

Wei, M., 1988. Ostracoda Biostratigraphy. Devonian Stratigraphy, Palaeontology and Sedimentary Facies. Geological Press, Beijing: 46-57, 277-314, 404-454.

Weyant, M., 1980. Les ostracodes. Mèmoires de la Sociètè gèologique et Minèralogique de Bretagne 23: 279-284.

Whatley, R. C., D. J. Siveter \& I. D. Boomer, 1993. Arthropoda (Crustacea: Ostracoda). In Benton, M. J. (ed.), The Fossil Record 2. Chapman and Hall, London, NY: 343-356.

Williams, M. \& P. J. Jones, 1990. On Eridoconcha simpsoni Harris. Stereo-Atlas of Ostracod Shells 17: 13-18.

Wilson, J. L., 1956. Stratigraphic position of the Upper Devonian branchiopod Rhabdostichus in the Williston Basin. Journal of Paleontology 30(4): 959-980.

Yamada, S., 2007a. Formation of the hinge in the podocopan ostracode Loxoconcha pulchra. Journal of Morphology 268: 442-456.

Yamada, S., 2007b. Structure and evolution of podocopan ostracod hinges. Biological Journal of the Linnean Society 92: 41-62.

Yamada, S. \& D. Keyser, 2009. Cuticle formation of the adductor muscle attachment in a podocopid ostracod, as an example of a calcified arthropod. Paleontological Research 13: 103-118.

Zagora, K., 1966. Die Gattung Eridoconcha Ulrich \& Bassler (Eridostraca) im Mitteldevon von Ost-Thüringen. Paläontologische Zeitschrift 40: 230-236. 